SRNL-STI-2010-00421

Revision 0

Keywords: Frit

SME

Dusting

De-Dusting

Water Content

Retention: Permanent

\title{
The Use of DI Water to Mitigate Dusting for Addition of DWPF Frit to the Slurry Mix Evaporator
}

M.W. Lambert

E.K. Hansen

August, 2010

Savannah River National Laboratory Savannah River Nuclear Solutions Aiken, SC 29808

Prepared for the U.S. Department of Energy under contract number DE-AC09-08SR22470.

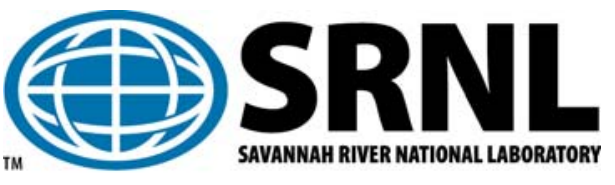


SRNL-STI-2010-00421

Revision 0

\section{DISCLAIMER}

This work was prepared under an agreement with and funded by the U.S. Government. Neither the U.S. Government or its employees, nor any of its contractors, subcontractors or their employees, makes any express or implied:

1. warranty or assumes any legal liability for the accuracy, completeness, or for the use or results of such use of any information, product, or process disclosed; or

2. representation that such use or results of such use would not infringe privately owned rights; or

3. endorsement or recommendation of any specifically identified commercial product, process, or service.

Any views and opinions of authors expressed in this work do not necessarily state or reflect those of the United States Government, or its contractors, or subcontractors.

\section{Printed in the United States of America \\ Prepared for \\ U.S. Department of Energy}


SRNL-STI-2010-00421

Revision 0

\section{REVIEWS AND APPROVALS}

AUTHORS:

M.W. Lambert, SCUREF

Date

E. K. Hansen Engineering Process Development

Date

TECHNICAL REVIEW:

M. E. Stone, Process Technology Programs

Date

APPROVAL:

C. C. Herman,

Date

E\&CPT Research Programs

S.L. Marra, Manager

Date

Environmental \& Chemical Process Technology Research Programs

J. E. Occhipinti

Date

SRR Engineering 
SRNL-STI-2010-00421

Revision 0

\section{EXECUTIVE SUMMARY}

The Defense Waste Processing Facility (DPWF) presently is in the process to determine means to reduce water utilization in the Slurry Mix Evaporator (SME) process, thus reducing effluent and processing times. The frit slurry addition system mixes the dry frit with water, yielding approximately a 50 weight percent slurry containing frit. This slurry is discharged into the SME and excess water is removed via boiling. To reduce this water load to the SME, DWPF has proposed using a pneumatic system in conveying the frit to the SME, in essence a dry delivery system. The problem associated with utilizing a dry delivery system with the existing frit is the generation of dust when discharged into the SME. Previous work performed by the Savannah River National Laboratory (SRNL) utilized wetting agents, including water, to mitigate dusting associated with the delivery of dry blended minerals for the Waste Treatment Plant located in Hanford, Washington. ${ }^{1}$ In the Hanford task, up to 5 weight percent of fluid was required to mitigate dusting. DWPF requested SRNL to perform essentially the same task, but limit wetting agents to water only.

SRNL analyzed six different DWPF frits, 165, 200, 304, 320, 418 and 510 (two different lots of Frit 418 and Frit 200 were tested). All frits but 165 meet DWPF particle size distribution specifications. The quantity of water required to mitigate dusting was determined by visually observing the outlet of a bench scale mixer that was used to mix the water with the frit. The wetted frits, as well as the dry frits were analyzed for particle size distribution, angle required to flow and residual mass of frit remaining on an aluminum oxide plate, and digital microscopy. The results from these tests are;

$>$ Frit 165 was unique to all the others, and had a smaller particle size distribution as compared to all the other frits.

$>$ For all frits, other than Frit 165, the average weight percent (wt $\%_{\mathrm{DD}}$ ) of deionized (DI) water added to the frit to de-dust was $0.95 \mathrm{wt} \%_{\mathrm{DD}}$ with a standard deviation of 0.11 wt $\%_{\text {DD }}$. The maximum weight percent of DI water for a given test was $1.17 \mathrm{wt} \%_{\mathrm{DD}}$.

$>$ For Frit 165, the average and maximum weight percent of DI water to de-dust was 3.05 and 3.11 weight percent respectively. This is expected, since this frit contained a larger fraction of smaller particles compared to the other frits.

$>$ Angled plate tests of wetted and dry frit on the aluminum oxide plate showed that the wetted frit required a higher angle to achieve flow and left more material on the plate when the plate was placed at 90 degrees.

$>$ None of the frits tested in this study reached the maximum fines content of the previously tested frits. Because of this, more water may be necessary than the results of these tests indicate.

$>$ Additional angled plate tests suggested that frit wetted to $2.0 \mathrm{wt} \%_{\mathrm{DD}}$ water flows better than frit wetted to $1.0 \mathrm{wt} \%$ DD. However, these tests were not extensive enough to be conclusive.

SRNL recommends the following if a dry feed delivery system is utilized for feed delivery to the SME;

$>$ Weight percent water determination for de-dusting for each vendor batch to be processed should be performed prior to processing the frit, if the frit will be pneumatically transported to the SME.

$>$ Use $1.2 \mathrm{wt} \%$ water to frit for scaled testing and/or proof of principle testing, for frit material that has been processed in the same manner as those tested in this report. 
$>$ Reduce the quantity of dust/fines present in future frit procurements. Dust reduction could potentially reduce the need for water for de-dusting. Pneumatic systems to remove fines are commercially available and should be evaluated.

$>$ Scaled testing should be performed to evaluate the amount of holdup in transfer lines and to determine whether flushing is required. 


\section{TABLE OF CONTENTS}

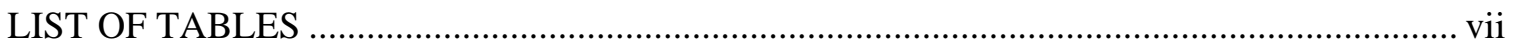

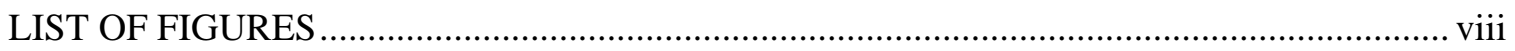

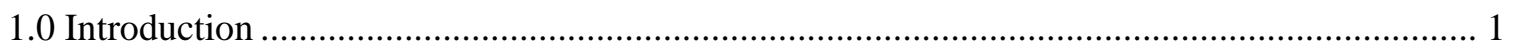

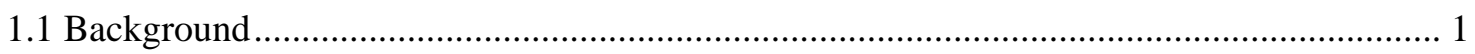

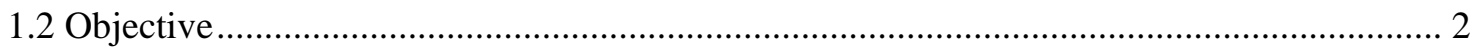

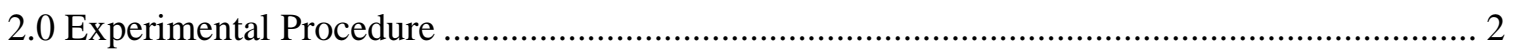

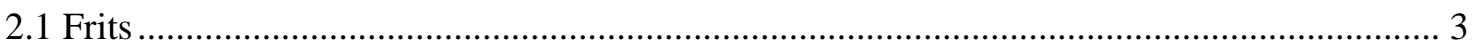

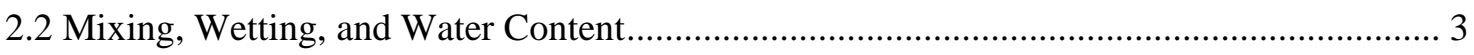

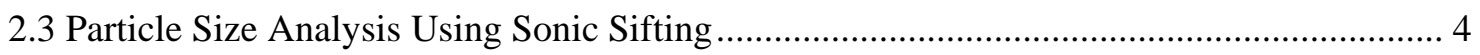

2.4 Angle of Flow and Residual Mass on Plate ........................................................................ 5

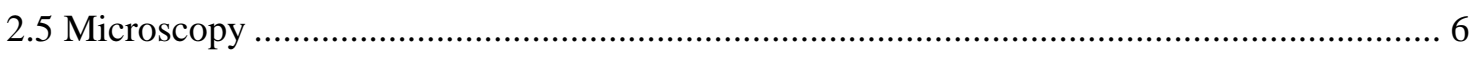

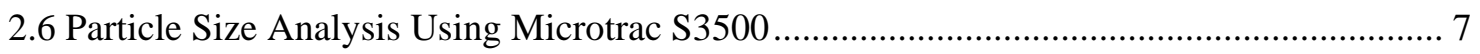

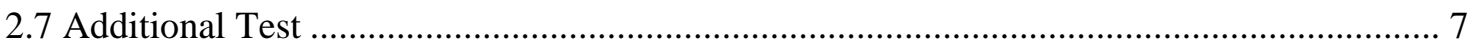

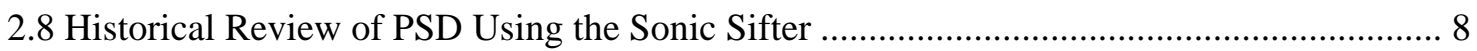

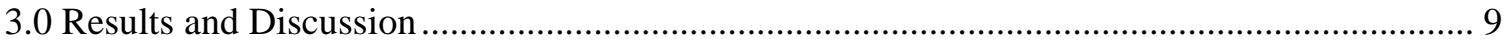

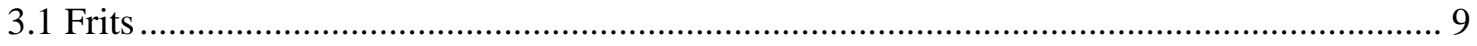

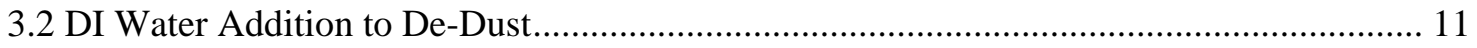

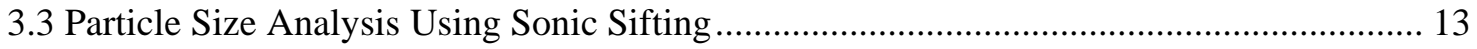

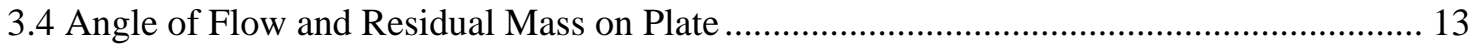

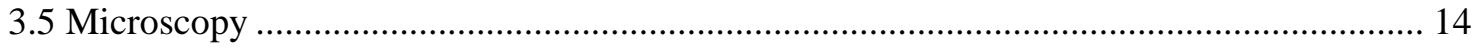

3.6 Particle Size Analysis Using Laser Light Refraction......................................................... 16

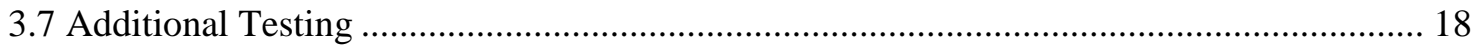

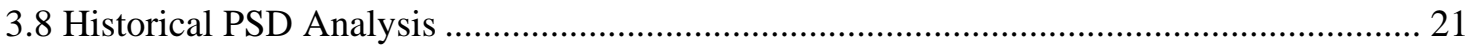

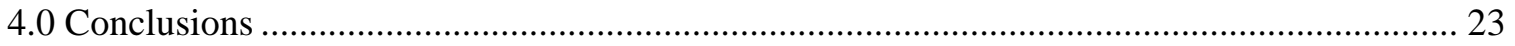

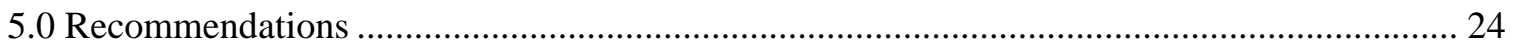

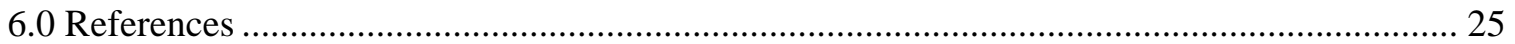




\section{LIST OF TABLES}

Table 2-1. Frits Tested To Determine Water Content for De-Dusting.......................................... 3

Table 3-1 Weight Percent Water Addition to De-Dust .............................................................. 11

Table 3-2 Weight Percent Particle Size Distribution Using the ATM Sonic Sifter ..................... 13

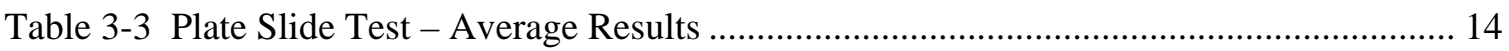

Table 3-4 Comparative Slide Test Results for Dry, 1 wt\% and 2 wt\% DI Water ....................... 14

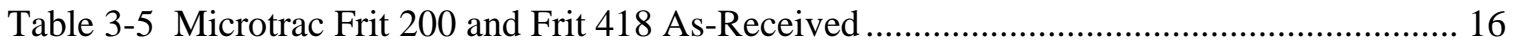

Table 3-6 Microtrac Frit 200 and Frit 418 Fines Particle Size Distribution................................. 17

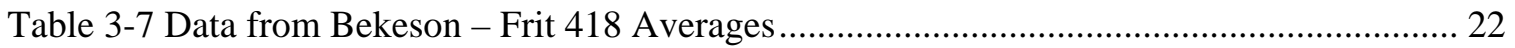

Table 3-8 Data from Ferro Corporation - Frit 418 Averages...................................................... 22 


\section{LIST OF FIGURES}

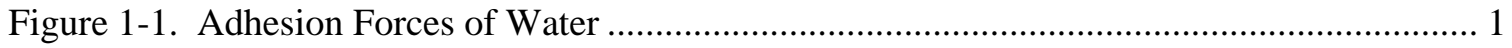

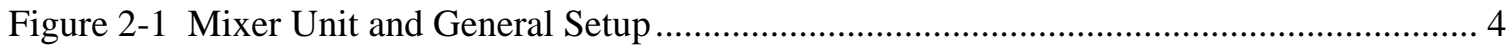

Figure 2-2 Dust Discharge and Lighting ................................................................................ 4

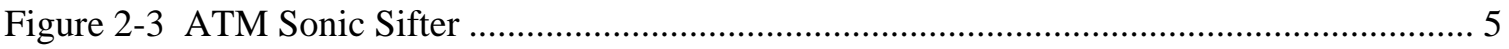

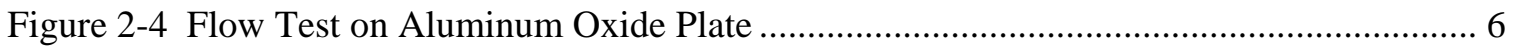

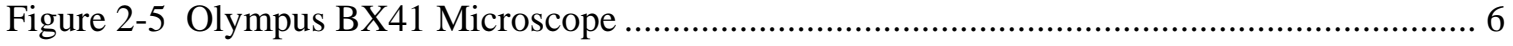

Figure 2-6 Frit 418 After 4 Minutes of Settling ….................................................................. 7

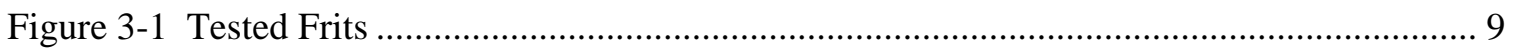

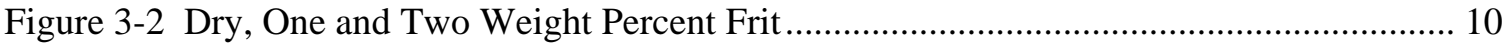

Figure 3-3 De-Dusting During the Addition of DI Water to Frit 320 ........................................ 12

Figure 3-4 Microscopy of Dry and De-Dusted Frit 320 …........................................................ 15

Figure 3-5 Microscopy of Dry and De-Dusted Frit 418 …......................................................... 15

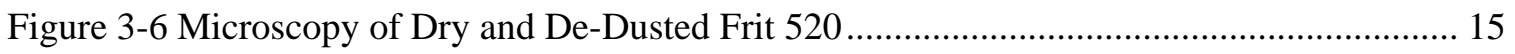

Figure 3-7 Fines in Frit 418 Observed using Microscope …........................................................ 18

Figure 3-8 Dusting Generation during Continuous Mixing ...................................................... 19

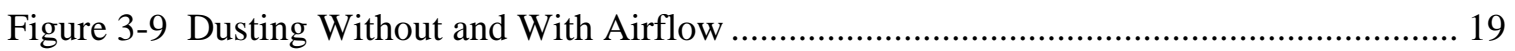

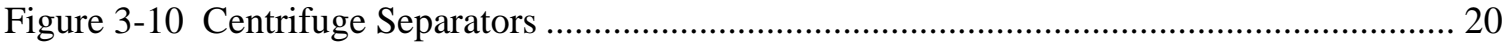

Figure 3-11 Taiheiyo Engineering Classiel Classifier............................................................... 20

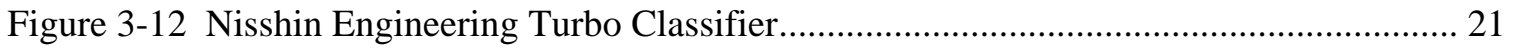

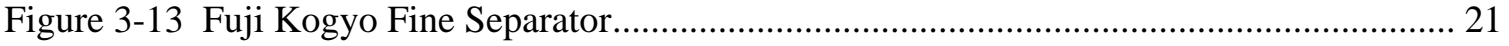




\section{LIST OF ABBREVIATIONS}

$\begin{array}{ll}\text { DI } & \text { De-ionized Water } \\ \text { DWPF } & \text { Defense Waster Processing Facility } \\ \text { PSD } & \text { Particle Size Distribution } \\ \text { SRNL } & \text { Savannah River National Laboratory } \\ \text { TT\&QAP } & \text { Technical Task and Quality Assurance Plan } \\ \text { Wt\% } & \text { Weight Percent of a given unit mass, different from wt\% }{ }_{\text {DD }} \\ & \text { Weight Percent mass of De-ionized water added to de-dust frit } \\ \text { wt }_{\mathrm{DD}} & \mathrm{wt}_{\mathrm{DD}}=\frac{\text { mass of DI water added to de-dust }}{\text { mass of frit }} \times 100 \%\end{array}$




\subsection{Introduction}

\subsection{Background}

The Defense Waste Processing Facility (DPWF) presently is in the process to determine means to reduce water utilization in the Slurry Mix Evaporator (SME) process, thus reducing effluent and processing times. The frit slurry addition system mixes the dry frit with water, yielding approximately a 50 weight percent slurry containing frit and the other fraction water. This slurry is discharged into the SME and excess water is removed via boiling. To reduce this water load to the SME, DWPF has proposed using a pneumatic system in conveying the frit to the SME, in essence a dry delivery system. The problem associated with utilizing a dry delivery system with the existing frit is the generation of dust when discharged into the SME.

The use of water has been shown to be effective in the mining industry ${ }^{2},{ }^{3}$ as well in the DOE complex $^{1}$ to mitigate dusting. The method employed ${ }^{1}$ by SRNL to determine the quantity of water to mitigate dusting in dry powders was effective, between a lab and bench scale tests. In those tests, it was shown that as high as five weight percent (wt\%) of water addition was required to mitigate dust from batches of glass forming minerals used by the Waste Treatment Plant at Hanford, Washington. The same method used to determine the quantity of water to mitigate dusting was used in this task to determine the quantity of water to mitigate this dusting using asreceived frit.

The ability for water to mitigate dusting is due to its adhesive properties as shown in Figure 1-1. Wetting the frit particles allows for the smaller frit particles (including dust) to adhere to the larger frit particles or to agglomerate into large particles. Fluids other than water can also be used, but their adhesive properties are different than water and the quantity required to mitigate dusting is different, as was observed in reference 1. Excessive water, a few weight percentages greater than that required to mitigate dusting can cause the resulting material not to flow.

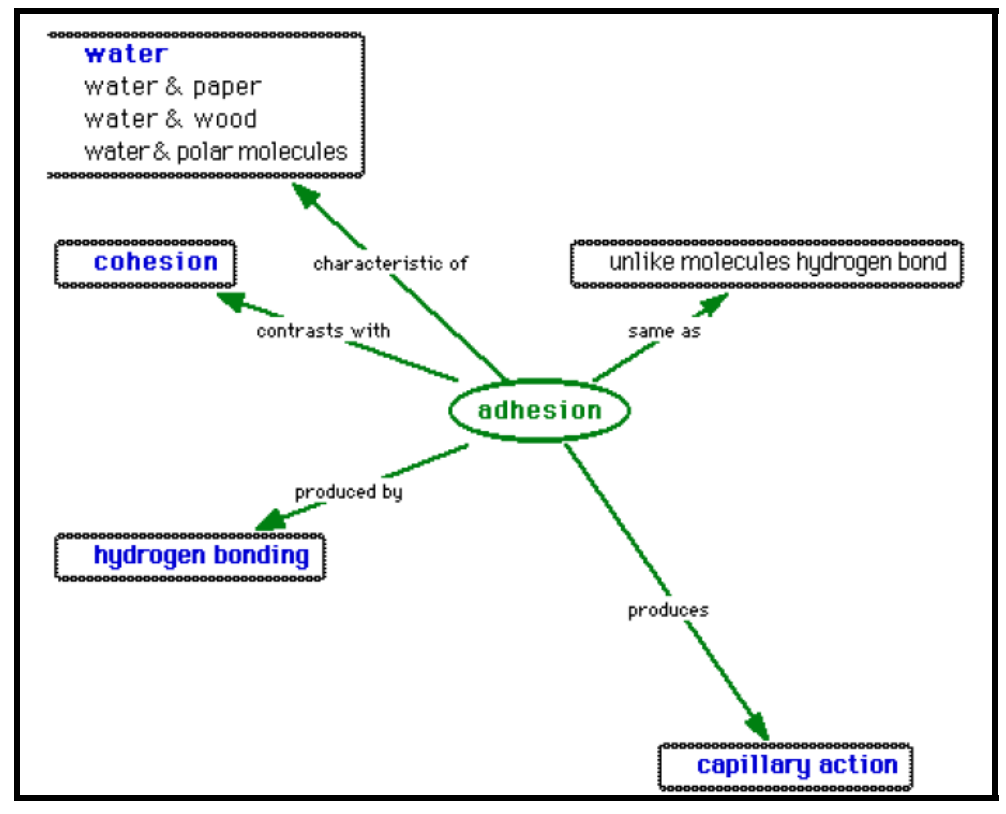

Figure 1-1. Adhesion Forces of Water 
SRNL-STI-2010-00421

Revision 0

\subsection{Objective}

The primary objective of this task is to perform bench scale testing on various frits that have been used at DWPF or in test programs at SRNL to determine the quantity of de-ionized (DI) water required to mitigate dusting per mass basis of frit. The quantity of DI water required was determined visually by observing the effluent port of the mixer, and DI water addition was made to the point where no visible dust was observed leaving the effluent port. A total of eight different frits were selected for testing.

Secondary objectives in this task include the following:

$>$ Video taping of the de-dusting procedure,

$>$ Particle size distribution analyses of the dry and wetted frits at the weight fraction of water required for de-dusting,

$>$ Plate flow tests to determine angle of flow and quantity of material remaining on plate at 90 degrees,

$>$ Microscopy of dry and wetted frit,

$>$ Effect of excess water for selected frits on plate flow.

The above analyses were performed within one hour of water addition, to minimize the effect of evaporative water losses.

To better understand the size of dust particles, perform settling tests on selected frits and capture the fines. Analyze the fines for particle size distribution.

Finally, it is expected that the surface area of frit is an important parameter in the quantity of water required for dust mitigation. An analysis of particle size distribution (PSD) data of asreceived frit analyzed by SRNL over the past two to three years will be performed to determine the variation in the distribution of as-received frit.

The following objectives were stated in the Technical Task Request ${ }^{4}$ as objectives that given adequate time would provide insight in helping DWPF in assessing equipment or processes for de-dusting and processing of dry frit. Due to time constraints, commercial methods for dedusting are provided. These results are detailed in section 3.7.

$>$ Obtain design information from Hanford with respective to equipment used for dedusting.

$>$ Suggestions on enhanced design features, such as flush water, pipe air purges, humidified compressed air, options for agitation, and other base (SRNL) knowledge.

The objectives and work accomplished in this report satisfy the task requirements and deliverables in the Technical Task Request, HLW-DWPF-TTR-2010-0013. ${ }^{4}$ The work accomplished in this report is controlled by the Task Technical and Quality Assurance Plan, SRNL-RP-2010-00958, Rev. $0 .^{6}$

\subsection{Experimental Procedure}

The tested frits, experimental procedures for wetting and determination of water content, particle size distribution, flow and residual solids on plate, and visual microscopy are provided below. 


\subsection{Frits}

The frits listed in Table 2-1 were tested in this report. The last column in this table provides the nomenclature used through out this report to designate the type of frit tested. Note that the letter "F" has been added to Frits 200 and 418 to designate Ferro as the vendor versus Bekeson. Common frit designations have common chemical makeup, meaning that they are within a range of values for each component. ${ }^{7}$

Table 2-1. Frits Tested To Determine Water Content for De-Dusting

\begin{tabular}{|c|c|c|c||}
\hline $\begin{array}{c}\text { Frit } \\
\text { Designation }\end{array}$ & Vendor & Lot\# & $\begin{array}{c}\text { Frit Designation in } \\
\text { Report }\end{array}$ \\
\hline 165 & American Porcelain & n/a & 165 \\
\hline 200 & n/a & BINKH76776H & 200 \\
\hline 200 & Ferro & SG530 & $200 \mathrm{~F}$ \\
\hline 304 & Specialty Glass inc. & 312021 & 304 \\
\hline 320 & Ferro & $320 \mathrm{~L} 22$ & 320 \\
\hline 418 & Bekeson & B030 & 418 \\
\hline 418 & Ferro & n/a & $418 \mathrm{~F}$ \\
\hline 510 & Bekeson & B009 & 510 \\
\hline
\end{tabular}

\subsection{Mixing, Wetting, and Water Content}

A Braun K 1000 food processor, Model 3210 was used as the mixer to observe the dust mitigation abilities of DI water for the various frits. This unit was set up with the mixing bowl and the internal drive arm whisking attachment and can be seen in Figure 2-1. The whisking attachment rotates around the periphery of the mixing bowl and the whisker rotates around its own shaft, providing excellent mixing of the dry materials. A hole had been drilled through the lid for a previous task to facilitate application of the wetting agent with a syringe and the filling tube was left open to observe the dust created during the mixer operation. The experimental set up is shown in Figure 2-1. Approximately 200 grams of frit was placed in the mixing bowl, the mixing attachment inserted, and the lid closed. The speed of the Braun mixer was set to 2.5 and the power turned on. A Dolan-Jenner Fiber Optic Light source was placed just above and to the side of the filling tube opening to illuminate a large portion of the dust stream exiting the tube, as observed in Figure 2-2. A Canon Mini-DV video camera was placed perpendicular to the light beam, and a blue background was placed behind the mixture to act as a contrast to the dust. The camera was used to visually document the dusting mitigation.

Once dusting was initially observed, water additions of approximately $0.2 \mathrm{~mL}$ were sprayed through the hole in the top and into the mixing path of the whisker at 20 second intervals. When the observed dusting became very sparse, water was added in $0.1 \mathrm{~mL}$ portions at 20 second intervals until no dusting was observed. The frit was then inspected and mixed by hand (swirling motion of the bowl) to ensure uniform mixing. The bowl was then replaced and mixing resumed. If dusting was observed, water additions continued at the normal mixing speed, until the dusting was completely mitigated. The weight percent DI water addition for de-dusting ( $\mathrm{wt} \%_{\mathrm{DD}}$ ) was calculated using equation [1].

$$
\text { wt } \%_{\text {DD }}=\frac{\text { mass of DI water added to de }- \text { dust }}{\text { mass of frit }} \times 100 \%
$$


Each frit was analyzed three times to determine the water content required for de-dusting. Approximately 20 grams of one of the de-dusted frit from each batch of frit was placed into a plastic bag for further characterization, which occurred immediately after the de-dusted frit was transferred into the plastic bag.

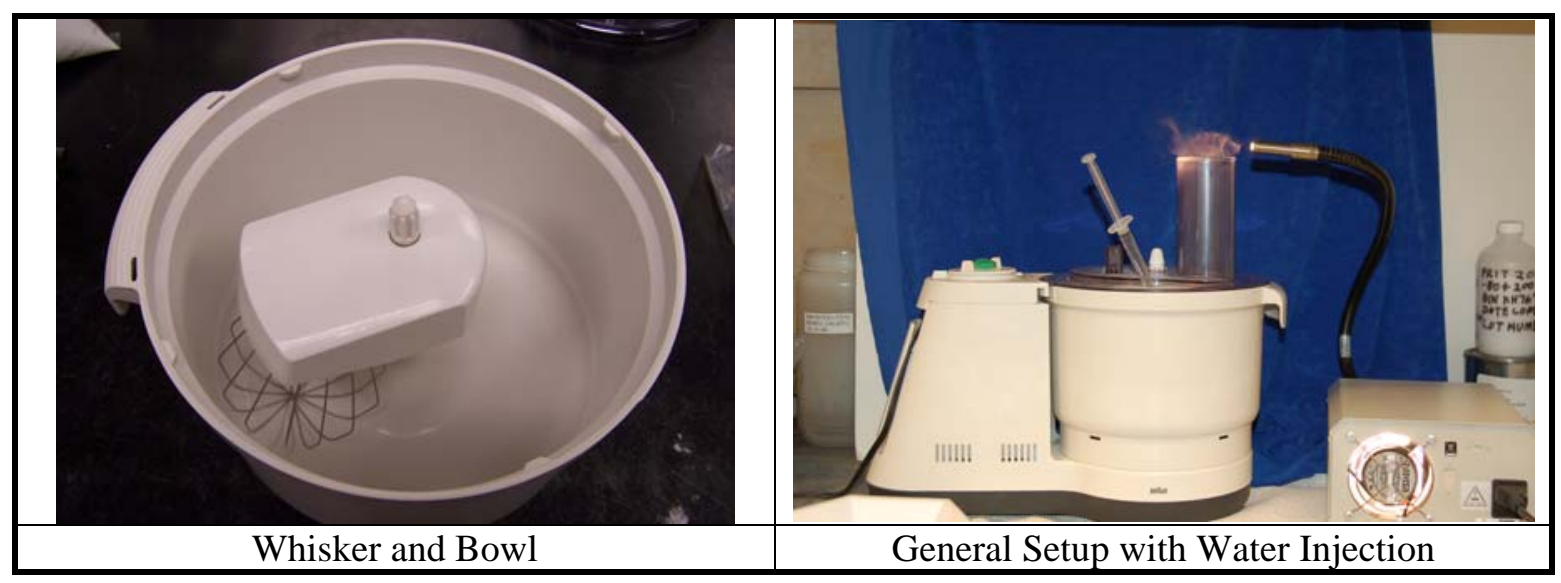

Figure 2-1 Mixer Unit and General Setup

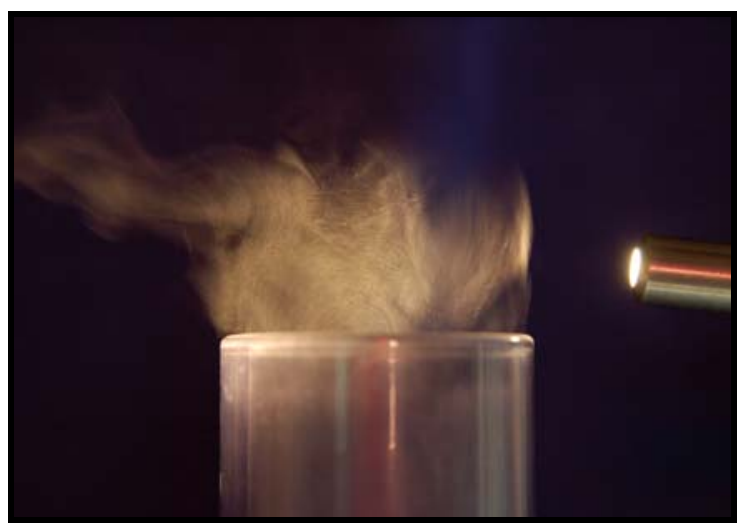

Figure 2-2 Dust Discharge and Lighting

\subsection{Particle Size Analysis Using Sonic Sifting}

The ATM Sonic Sifter was selected for particle size distribution (PSD), given that this instrument is utilized by SRNL to provide DWPF particle size analysis of frit to be utilized by DWPF for processing, hence it has historical use. ${ }^{\mathrm{a}}$. In this study, the same sieve sizes typically used to report the PSD were used, 250, 177, 105, 75 and 38 microns. In addition a final 20 micron size mesh was added to capture smaller particles. Prior to the measurement, each sieve, the top cone and diaphragm, and the base and fines collector were weighed to obtain their tare value. The sieves are stacked, with the smallest sieve at the bottom of the stack and progressing upwards with larger and larger sieves, as shown in Figure 2-3. The base and the sieves were placed on the scale, the scale tared, a sample of approximately three grams placed into the $250 \mu \mathrm{m}$ sieve, and the

${ }^{a}$ Per conversation with David Best who provides the data to DWPF for particle size distribution of as received frit from outside vendors. 
exact sample mass recorded. The sieve stack was then placed in the ATM Ultra Sonic Sifter (see Figure 2-3), the settings set at sift/pulse with an intensity of nine and sift/pulsed for three and onehalf minutes. The stack was removed, and each component of the stack was weighed and its weight recorded. The sieves were cleaned using dry compressed air, and this procedure was carried out three times for a sample set. Both dry and de-dusted samples were analyzed using this method. Note that the ASTM Sonic Sifter is a mechanical device that vibrates the sieves and shocks (thumps) the stack of sieves and the environment is not controlled. Hence evaporative losses and breaking of the de-dusted frit particles into smaller particles can occur during this measurement.

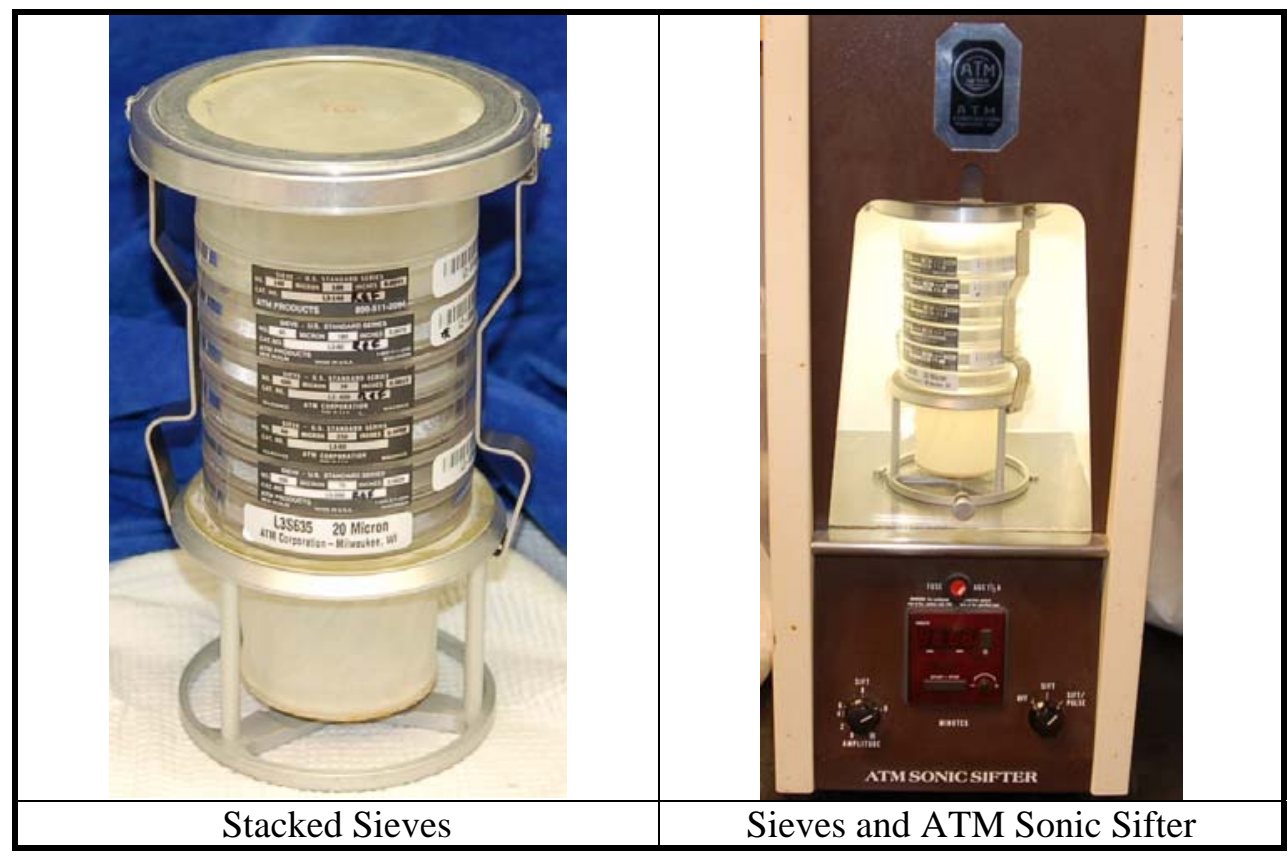

Figure 2-3 ATM Sonic Sifter

\subsection{Angle of Flow and Residual Mass on Plate}

Simple flow tests were performed to qualify the effect of how water can impact the flow and adhesion of frit to an aluminum oxide coated plate. The aluminum oxide coated plate (see Figure 2-4) was provided by DWPF as one of the materials that could potentially be used in the transfer line, due the very abrasive characteristics of frit. The aluminum oxide coated plate was initially weighed. Then a sample of frit (approximately 0.6 grams) was placed on the plate. The plate was then raised until the material began to flow, see Figure 2-4. An Empire Polycast Magnetic Protractor was used to determine this angle and the angle was recorded. The plate was then raised to 90 degrees and the amount of frit remaining on the plate measured. This procedure was carried out three times for each sample, for both dry and de-dusted samples.

Additional tests with the aluminum oxide plate were performed comparing three different water contents, none, 1 wt $\%_{\mathrm{DD}}$ and $2 \mathrm{wt} \%$ DD for Frit 320, Frit 418 and Frit 510. Sub-samples of frit containing the various water contents were placed on the plate and the plate angle increased until each of the sample slide down the plate, qualifying the effect of water content. 


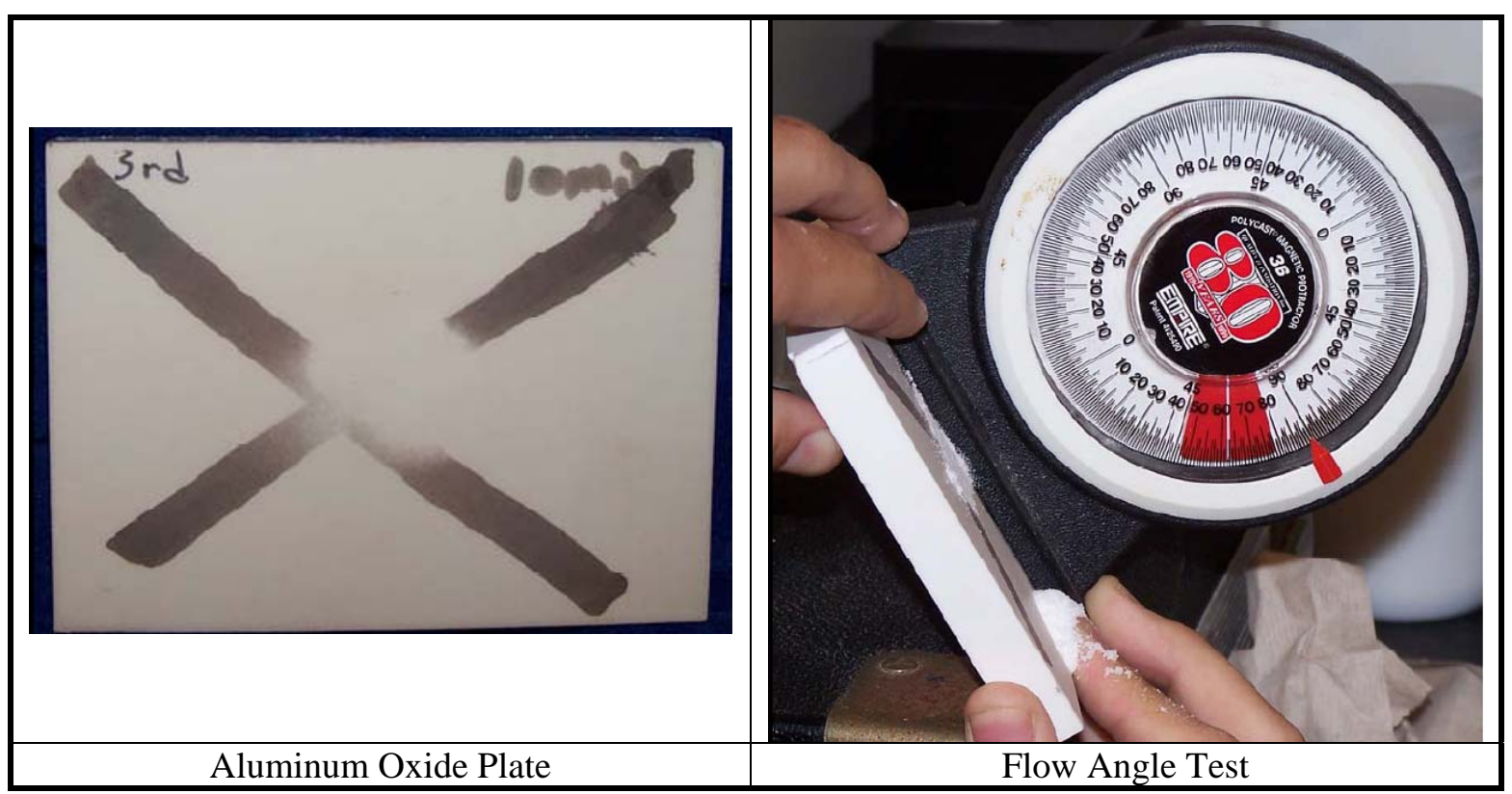

Figure 2-4 Flow Test on Aluminum Oxide Plate

\subsection{Microscopy}

Within one hour of the wetting tests, digital pictures of dry and wetted frit were obtained using an Olympus BX41 Microscope (see Figure 2-5) along with a Photometrics Coolsnap CF Camera. Comparisons of the wet and dry frits were analyzed for changes in presence of dust, particle size, and particle cohesion.

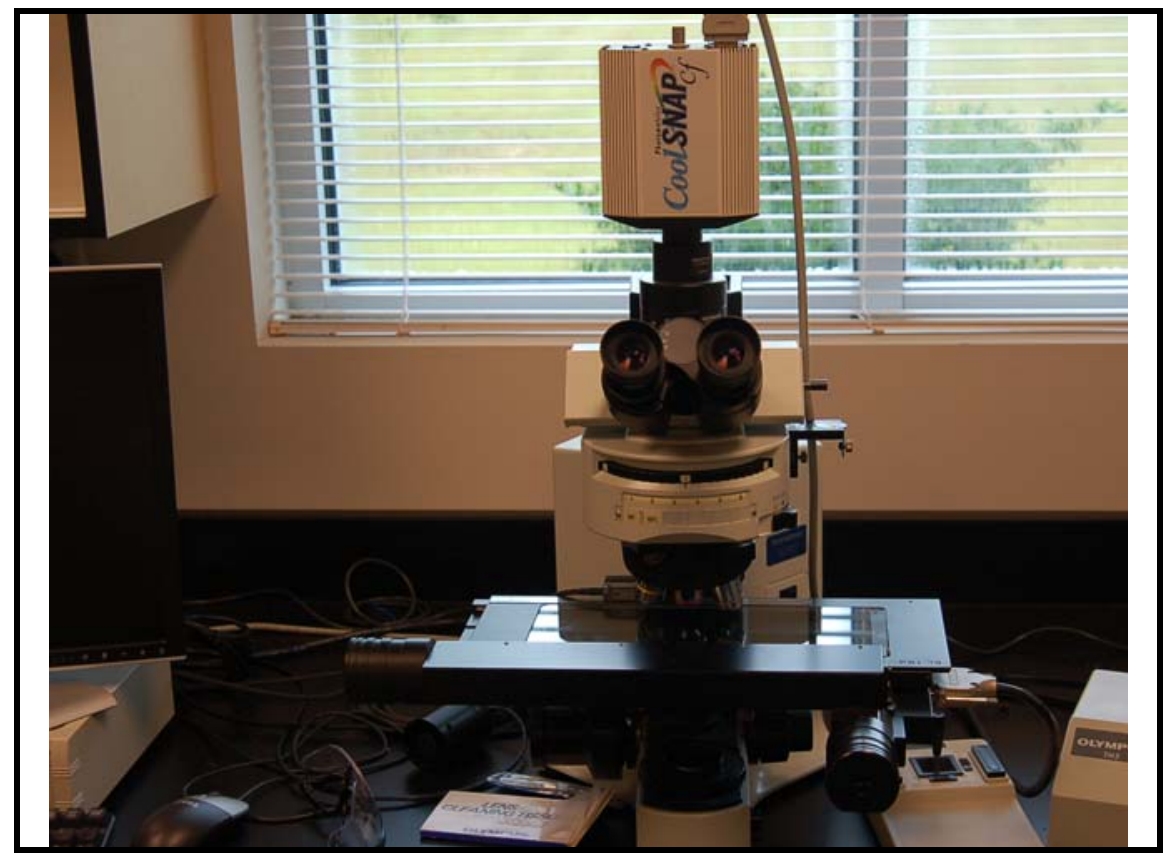

Figure 2-5 Olympus BX41 Microscope 


\subsection{Particle Size Analysis Using Microtrac S3500}

The Microtrac S3500 uses Tri-Laser Technology. The Tri-Laser System uses precise angular measurements of scattered light through a full 180 degree angular range with three lasers and two detector arrays. The scattered light is analyzed using the Mie Based unified angular scattering theory from large particle analysis to small particle analysis to determine particle size analysis. The data can be reported as volume or number basis. The data is represented as though the particles are spherical in shape. This is not the case, since frit is very angular in shape.

The Microtrac S3500 will be used to determine both the PSD of as-received frit and that of fines gather via settling. To obtain the fines, frit was placed into a bottle, DI water added, mixed and allowed to settle for four minutes to let the +20 micron particles to settle (see Figure 2-6). The supernate, containing the fines were then removed for analysis. Two different frits were analyzed, Frit 200 and Frit 418. A sub-sample of the Frit 418 fines was observed using the microscopy.

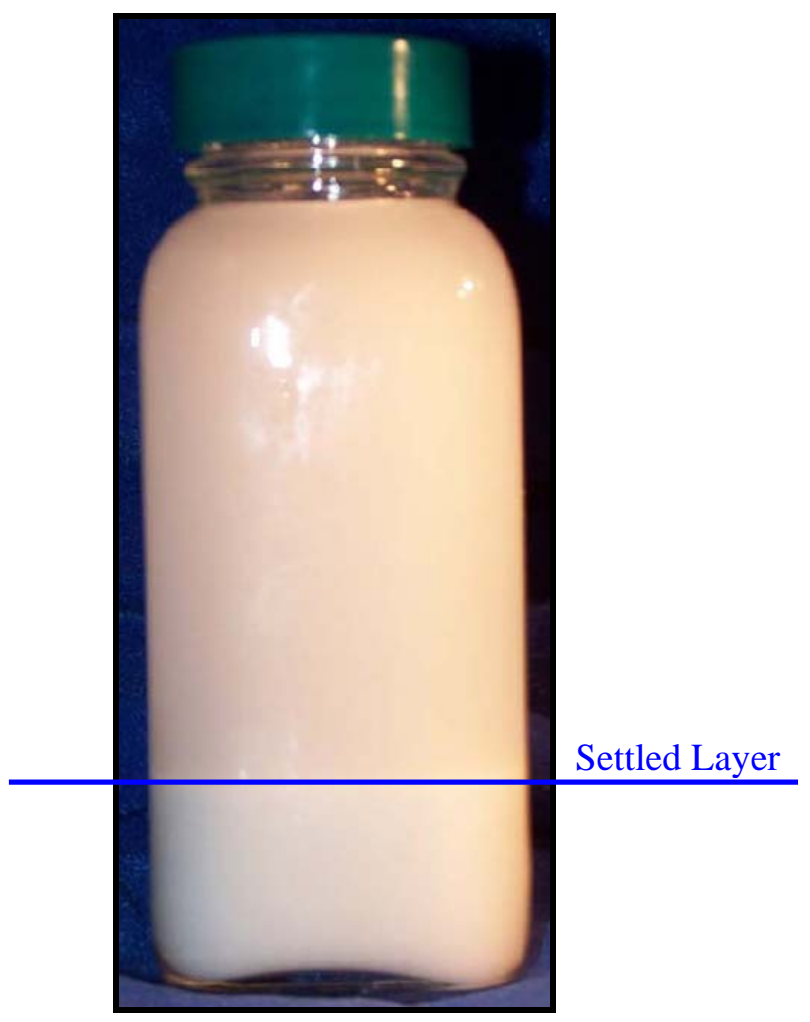

Figure 2-6 Frit 418 After 4 Minutes of Settling

\subsection{Additional Test}

SRNL performed two additional tests with the mixer with dry frit:

1. Run mixer for one hour and determine if dust generation is constant

2. Run mixer, using new batch of frit and apply air flow into the mixing chamber and show impact on discharge. 
SRNL-STI-2010-00421

Revision 0

\subsection{Historical Review of PSD Using the Sonic Sifter}

Analysis of the comprehensive work done by David Best characterizing the properties of various lots of DWPF Frit 418 by both Ferro Corporation and Bekeson Glass over the past few years will provide some insight into the variation in frits by both companies. This data was analyzed to determine the variability in the particle size distribution of the supplied frits and will be compared to the frits that were analyzed in this task. 


\subsection{Results and Discussion}

\subsection{Frits}

The frits tested in this task are shown in Figure 3-1. All the frits other than Frit 165 had essentially the same type of characteristics when laid out on a dark coated surface. Frit 165 has the characteristic of a fine powder as compared to the other frits, which had more favorable flow characteristics. Note that the other frits $(200,304,320,418$ and 510) show speckles of frit particles away from the mounds, unlike Frit 165.

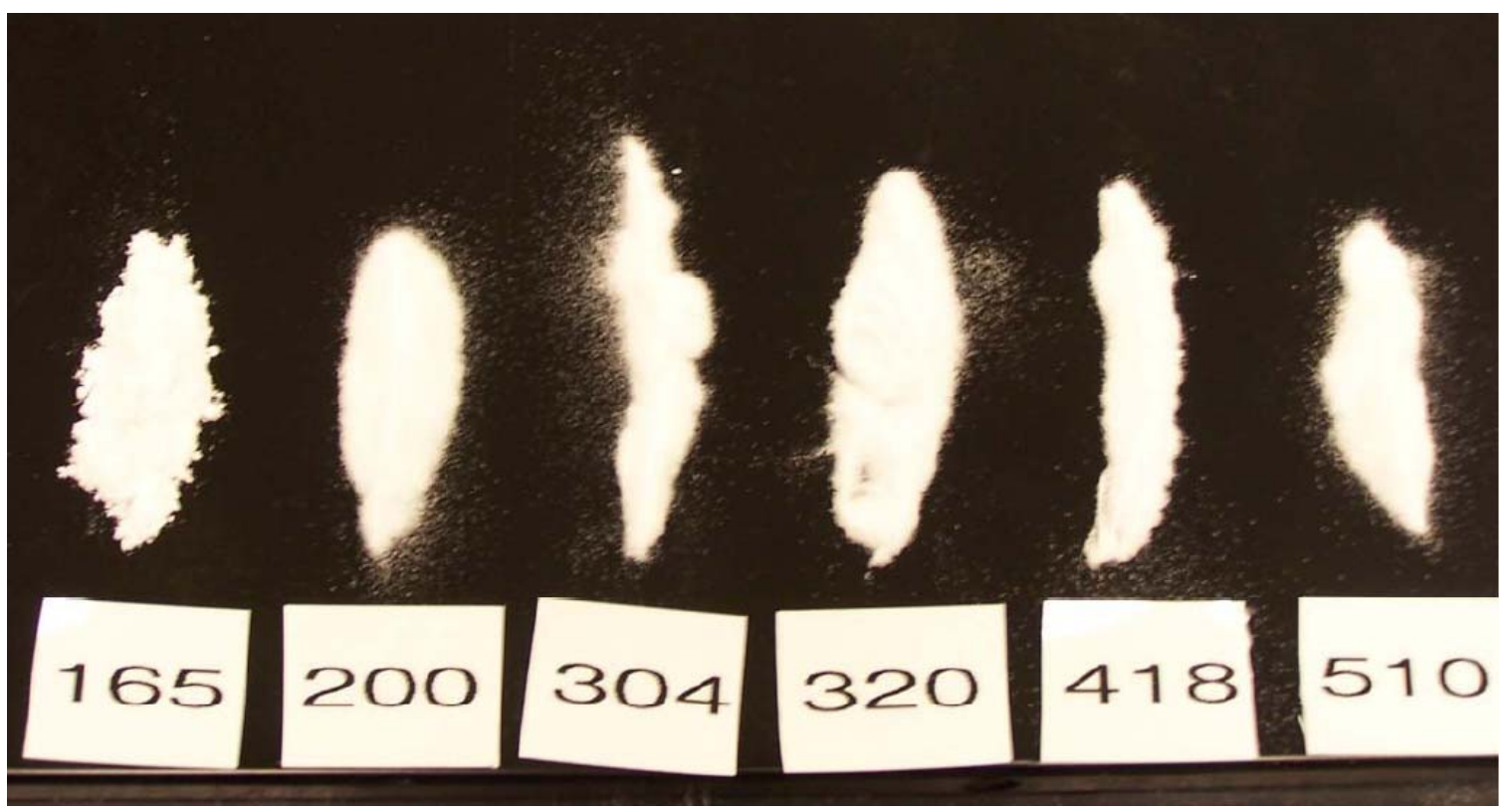

Figure 3-1 Tested Frits

Pictures were obtained of frits with different concentrations of DI water, dry, $1 \mathrm{wt} \%_{\mathrm{DD}}$, and 2 wt $\%_{\text {DD }}$. Figure 3-2 shows the effect of water content for Frit 320, Frit 418 and Frit 510 in a plastic bag. These samples were made to determine the impact of water content on angle of flow. The pictures clearly show the dry frits do not form visible agglomerates like the one and two wt\% DI water additions. This shows the cohesive effects of water on frit. 


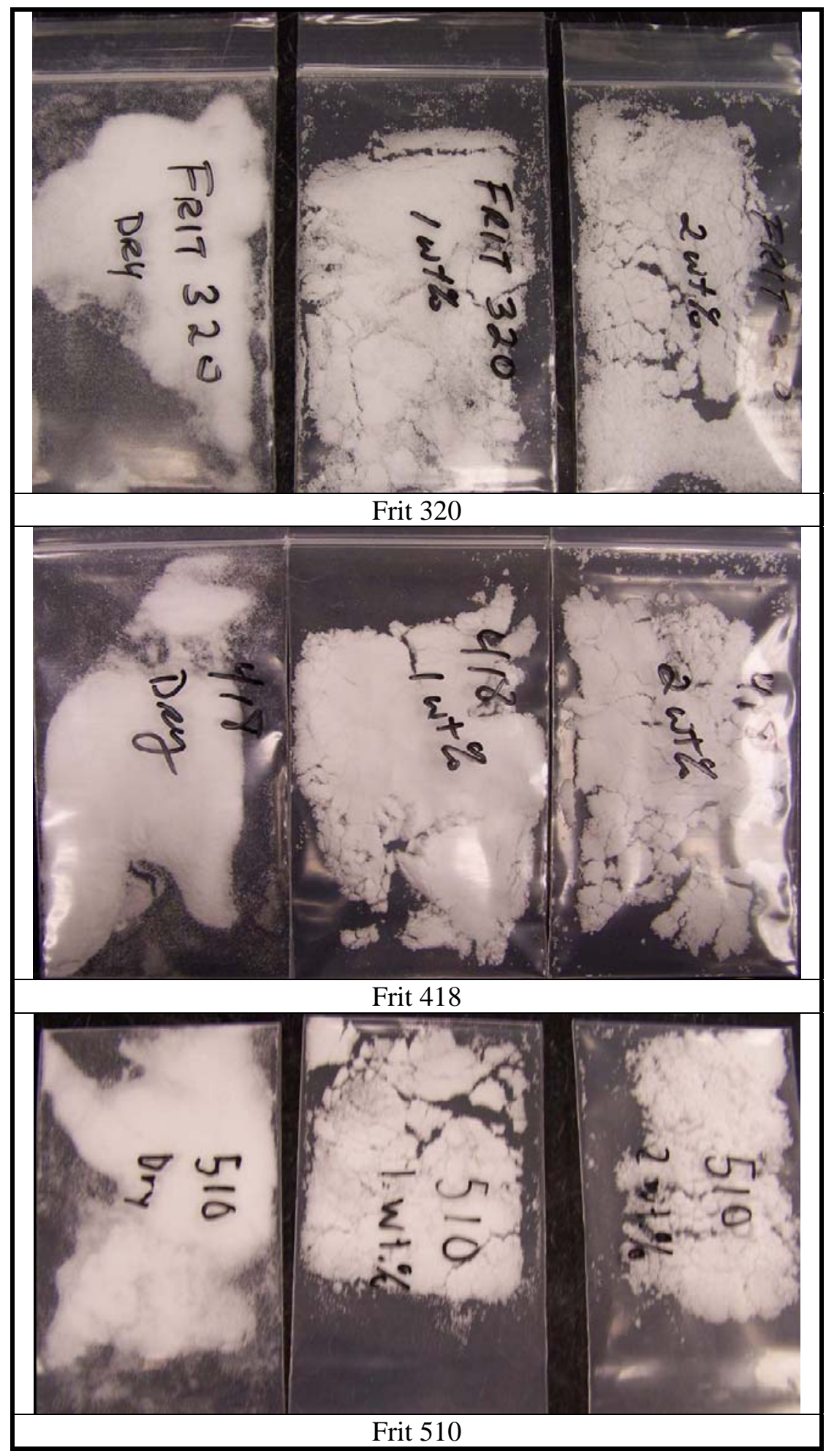

Figure 3-2 Dry, One and Two Weight Percent Frit 


\subsection{Water Addition to De-Dust}

The weight percent of DI water required to de-dust the various frits are provided in Table 3-1. The data clearly shows that Frit 165 required more water, due to it being a powder (greater fines content). The other frits $(200,304,320,418$, and 510$)$ required essentially the same wt ${ }_{\mathrm{DD}}$ water, with average value of $0.95 \mathrm{wt} \%_{\mathrm{DD}}$ and a standard deviation of $0.11 \mathrm{wt} \%_{\mathrm{DD}}$. For the other frits, the maximum DI water requirement was $1.17 \mathrm{wt} \%_{\mathrm{DD}}$. In general, the addition of approximately 0.6 to $0.8 \mathrm{~mL}$ of $\mathrm{DI}$ water $\left(0.3\right.$ to $\left.0.4 \mathrm{wt} \%_{\mathrm{DD}}\right)$ drastically reduced the amount of dusting as shown in Figure 3-3 and was consistent with all the other frits, other than Frit 165.

Table 3-1 Weight Percent Water Addition to De-Dust

\begin{tabular}{|c|c|c|c|c|c|}
\hline \multirow{2}{*}{$\begin{array}{c}\text { FRIT } \\
\text { TYPE }\end{array}$} & \multirow{2}{*}{ Lot \# } & Weight Percent Water Addition to De-Dust \\
\cline { 3 - 6 } & & Average & $\begin{array}{c}\text { Std. } \\
\text { Dev.* }\end{array}$ & $\begin{array}{c}\text { Percent } \\
\text { Std. } \\
\text { Dev. }\end{array}$ & Max \\
\hline 165 & n/a & $3.05 \%$ & $0.06 \%$ & $2.6 \%$ & $3.11 \%$ \\
\hline 200 & BINKH76776H & $0.82 \%$ & $0.06 \%$ & $7.6 \%$ & $0.88 \%$ \\
\hline $200 \mathrm{~F}$ & SG530 & $0.94 \%$ & $0.02 \%$ & $2.0 \%$ & $0.95 \%$ \\
\hline 304 & 312021 & $0.88 \%$ & $0.04 \%$ & $5.1 \%$ & $0.93 \%$ \\
\hline 320 & $320 \mathrm{~L} 22$ & $0.87 \%$ & $0.05 \%$ & $0.9 \%$ & $0.92 \%$ \\
\hline 418 & B030 & $1.08 \%$ & $0.07 \%$ & $6.2 \%$ & $1.14 \%$ \\
\hline $418 \mathrm{~F}$ & n/a & $1.10 \%$ & $0.11 \%$ & $10.1 \%$ & $1.17 \%$ \\
\hline 510 & B009 & $0.96 \%$ & $0.04 \%$ & $0.9 \%$ & $1.01 \%$ \\
\hline
\end{tabular}

* Std. Dev. = Standard Deviation 


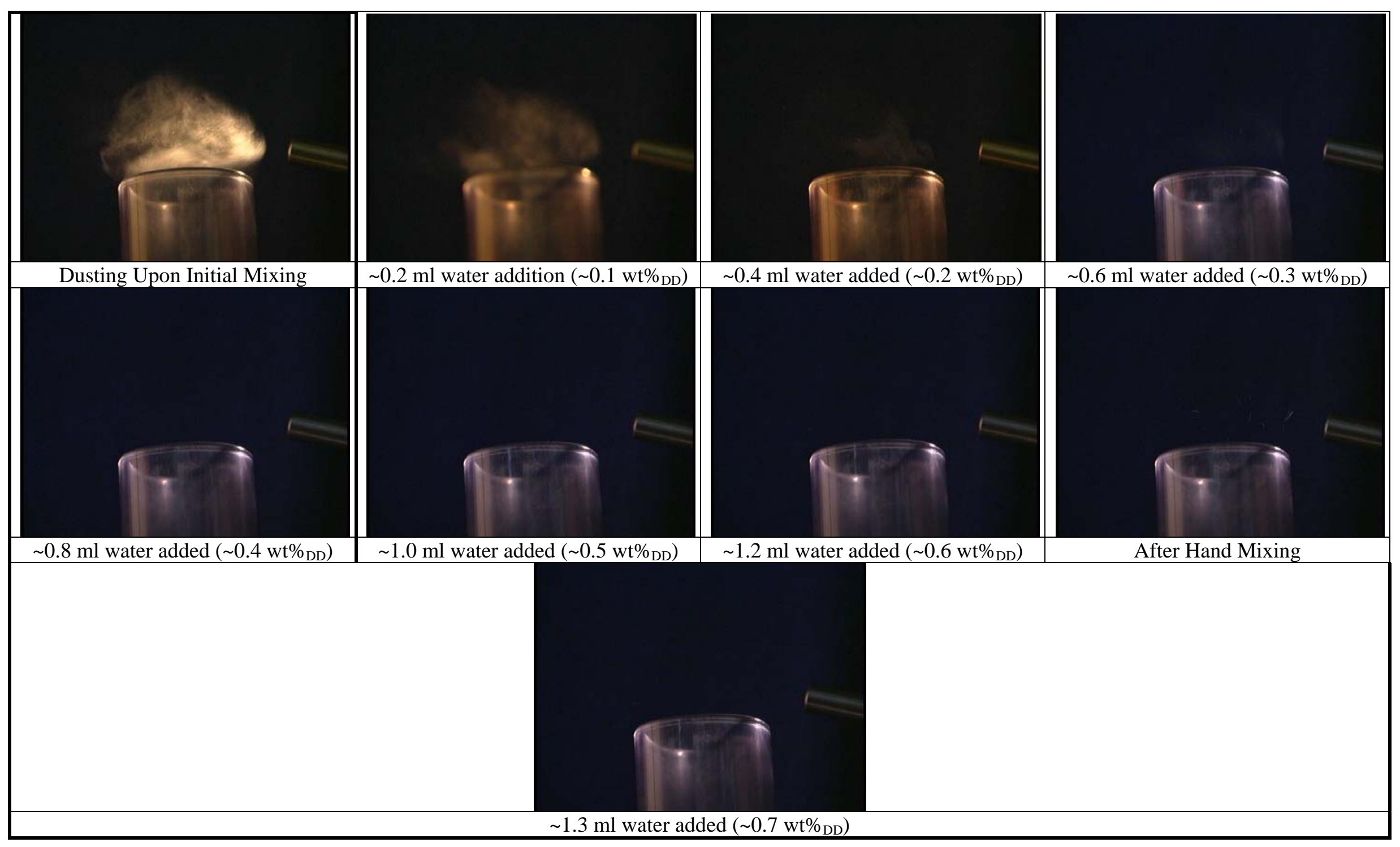

Figure 3-3 De-Dusting During the Addition of DI Water to Frit 320 


\subsection{Particle Size Analysis Using Sonic Sifting}

The particle size distributions using the ATM Sonic Sifter for the dry and de-dusted frits are provided in Table 3-2. In generalities, the de-dusted frit resulted in large particles as compared to the dry frit, due to the agglomeration of the fines and smaller particles. The Frit 200F and Frit 418F de-dusted frits were not analyzed, since their dry PSD were similar to the Frit 200 and Frit 418. Frit 200 and 320 dry and de-dusted PSD were very similar.

Table 3-2 Weight Percent Particle Size Distribution Using the ATM Sonic Sifter

\begin{tabular}{|c|c|c|c|c|c|c|c|c|}
\hline \multirow{4}{*}{ Sieve Size } & \multicolumn{8}{|c|}{ FRIT TYPE / Lot \# } \\
\hline & \multicolumn{2}{|c|}{165} & \multicolumn{2}{|c|}{200} & \multicolumn{2}{|c|}{$200 \mathrm{~F}$} & \multicolumn{2}{|c|}{304} \\
\hline & \multicolumn{2}{|c|}{$\mathrm{n} / \mathrm{a}$} & \multicolumn{2}{|c|}{ BINKH76776H } & \multicolumn{2}{|c|}{ SG530 } & \multicolumn{2}{|c|}{312021} \\
\hline & Dry & $\begin{array}{c}\text { De- } \\
\text { dusted }\end{array}$ & Dry & $\begin{array}{c}\text { De- } \\
\text { dusted }\end{array}$ & Dry & $\begin{array}{c}\text { De- } \\
\text { dusted }\end{array}$ & Dry & $\begin{array}{l}\text { De- } \\
\text { dusted }\end{array}$ \\
\hline $250 \mu \mathrm{m}$ & $2.9 \%$ & $37.2 \%$ & $0.0 \%$ & $0.1 \%$ & $0.5 \%$ & - & $0.1 \%$ & $6.9 \%$ \\
\hline $177 \mu \mathrm{m}$ & $5.5 \%$ & $27.4 \%$ & $0.1 \%$ & $0.2 \%$ & $0.3 \%$ & - & $0.1 \%$ & $9.2 \%$ \\
\hline $105 \mu \mathrm{m}$ & $30.3 \%$ & $23.6 \%$ & $67.8 \%$ & $69.5 \%$ & $64.9 \%$ & - & $48.4 \%$ & $53.5 \%$ \\
\hline $75 \mu \mathrm{m}$ & $18.2 \%$ & $6.3 \%$ & $29.1 \%$ & $26.7 \%$ & $28.2 \%$ & - & $46.4 \%$ & $28.5 \%$ \\
\hline $38 \mu \mathrm{m}$ & $25.7 \%$ & $5.3 \%$ & $3.0 \%$ & $3.5 \%$ & $6.0 \%$ & - & $4.9 \%$ & $1.8 \%$ \\
\hline $20 \mu \mathrm{m}$ & $12.2 \%$ & $0.2 \%$ & $0.0 \%$ & $0.0 \%$ & $0.1 \%$ & - & $0.2 \%$ & $0.1 \%$ \\
\hline \multirow{4}{*}{ Sieve Size } & \multicolumn{8}{|c|}{ FRIT TYPE / Lot \# } \\
\hline & \multicolumn{2}{|c|}{320} & \multicolumn{2}{|c|}{418} & \multicolumn{2}{|c|}{$418 \mathrm{~F}$} & \multicolumn{2}{|c|}{510} \\
\hline & \multicolumn{2}{|c|}{ 320L22 } & \multicolumn{2}{|c|}{ B030 } & \multicolumn{2}{|c|}{$\mathrm{n} / \mathrm{a}$} & \multicolumn{2}{|c|}{ B009 } \\
\hline & Dry & $\begin{array}{c}\text { De- } \\
\text { dusted }\end{array}$ & Dry & $\begin{array}{c}\text { De- } \\
\text { dusted }\end{array}$ & Dry & $\begin{array}{c}\text { De- } \\
\text { dusted }\end{array}$ & Dry & $\begin{array}{c}\text { De- } \\
\text { dusted }\end{array}$ \\
\hline $250 \mu \mathrm{m}$ & $0.0 \%$ & $0.3 \%$ & $0.6 \%$ & $3.8 \%$ & $0.2 \%$ & - & $0.1 \%$ & $7.1 \%$ \\
\hline $177 \mu \mathrm{m}$ & $0.2 \%$ & $0.3 \%$ & $1.8 \%$ & $4.4 \%$ & $0.2 \%$ & - & $0.8 \%$ & $5.8 \%$ \\
\hline $105 \mu \mathrm{m}$ & $72.8 \%$ & $72.9 \%$ & $61.3 \%$ & $62.0 \%$ & $63.5 \%$ & - & $63.1 \%$ & $58.4 \%$ \\
\hline $75 \mu \mathrm{m}$ & $23.8 \%$ & $22.4 \%$ & $30.3 \%$ & $25.1 \%$ & $32.7 \%$ & - & $32.9 \%$ & $25.6 \%$ \\
\hline $38 \mu \mathrm{m}$ & $3.2 \%$ & $4.1 \%$ & $6.0 \%$ & $4.7 \%$ & $3.3 \%$ & - & $3.0 \%$ & $3.0 \%$ \\
\hline $20 \mu \mathrm{m}$ & $0.0 \%$ & $0.1 \%$ & $0.1 \%$ & $0.0 \%$ & $0.1 \%$ & - & $0.1 \%$ & $0.1 \%$ \\
\hline
\end{tabular}

\subsection{Angle of Flow and Residual Mass on Plate}

The results from the angle of flow and residual mass of both dry and de-dusted frits on the aluminum oxide plate are provided in Table 3-3. The results indicate that for the de-dusted frits, the angle for flow and weight percent retained on the plate at 90 degrees are greater for the dedusted frits. These large responses are most likely due to the cohesive natural of the water in the frit, at the lowest water content to mitigate dusting. Dry frit was also present on the plate, which could be both the attractive electrostatic potential between the plate and frit particles and the roughness of the plate itself.

Additional angle of flow tests were performed by placing dry, one weight percent and two weight percent water to Frit 320, Frit 418, and Frit 510 onto the aluminum oxide plate. The plate was lifted slowly to 90 degrees, and the order in which the frits began to flow was recorded. Three trials were performed for each frit. The results are tabulated in Table $3-4$. The $2.0 \mathrm{wt} \%_{\mathrm{DD}}$ water 
frit flowed first in five out of the nine trials performed while the dry frit flowed first for three out of the nine trials. The $1.0 \mathrm{wt} \%$ DD frit flowed last in eight of the nine trials. This suggests that the flow abilities of wetted frit may increase with water fraction at lower weight percentages. This may occur because the particle to particle cohesive strength increases with water fraction more so than its adhesive properties. Additionally, The $2.0 \mathrm{wt} \%_{\mathrm{DD}}$ frit seemed to more readily form balls when wetted while the clusters of $1.0 \mathrm{wt} \%$ DD water frit were observed to stick together in more plate-like formations. These would have more surface area touching the plate which would allow for stronger adhesion and worsen flow properties.

Table 3-3 Plate Slide Test - Average Results

\begin{tabular}{|c|c|c|c|c|c|}
\hline \multirow{2}{*}{$\begin{array}{c}\text { FRIT } \\
\text { TYPE }\end{array}$} & \multirow{2}{*}{ Lot \# } & Dry & $\begin{array}{c}|c| \\
\text { De- } \\
\text { dusted }\end{array}$ & Dry & $\begin{array}{c}\text { De- } \\
\text { dusted }\end{array}$ \\
\cline { 3 - 6 } & n/a & 55 & 69 & $2.8 \%$ & $8.9 \%$ \\
\hline 200 & BINKH76776H & 45 & 51 & $0.7 \%$ & $1.9 \%$ \\
\hline $200 \mathrm{~F}$ & SG530 & 50 & - & $2.2 \%$ & - \\
\hline 304 & 312021 & 40 & 65 & $1.0 \%$ & $26.8 \%$ \\
\hline 320 & $320 \mathrm{~L} 22$ & 44 & 57 & $0.9 \%$ & $3.1 \%$ \\
\hline 418 & B030 & 45 & 76 & $1.2 \%$ & $3.7 \%$ \\
\hline $418 \mathrm{~F}$ & $\mathrm{n} / \mathrm{a}$ & 46 & - & $1.3 \%$ & - \\
\hline 510 & $\mathrm{~B} 009$ & 42 & 71 & $0.3 \%$ & $30.7 \%$ \\
\hline
\end{tabular}

Table 3-4 Comparative Slide Test Results for Dry, 1 wt\% and 2 wt\% DI Water

\begin{tabular}{|c|c|c|c|}
\hline Frit/Run & \multicolumn{3}{|c|}{ Slide Order } \\
\hline Frit 418 & 1st & 2nd & 3rd \\
\hline I & $2 \%$ & dry & $1 \%$ \\
\hline II & $2 \%$ & dry & $1 \%$ \\
\hline III & dry & $2 \%$ & $1 \%$ \\
\hline \hline Frit 510 & 1st & 2nd & 3rd \\
\hline I & $2 \%$ & dry & $1 \%$ \\
\hline II & $2 \%$ & dry & $1 \%$ \\
\hline III & dry & $2 \%$ & $1 \%$ \\
\hline \hline Frit 320 & 1st & 2nd & 3 rd \\
\hline I & dry & $2 \%$ & $1 \%$ \\
\hline II & $2 \%$ & dry & $1 \%$ \\
\hline III & $1 \%$ & dry & $2 \%$ \\
\hline
\end{tabular}

\section{5 $\underline{\text { Microscopy }}$}

The microscopy at a magnification of 10X for three different frits, 320, 418, and 520 are shown in Figure 3-4, Figure 3-5, and Figure 3-6 respectively. In general, the application of water required for de-dusting causes agglomeration of particles and the removal of fines within the agglomerates. The small uniform specks observed in Figure 3-5, and Figure 3-6 are not dust particles. Instead it is believed that these specks are small water droplets (or water stains) that were generated when trying to place and spread the de-dusted frits in preparation for the microscopy pictures. 


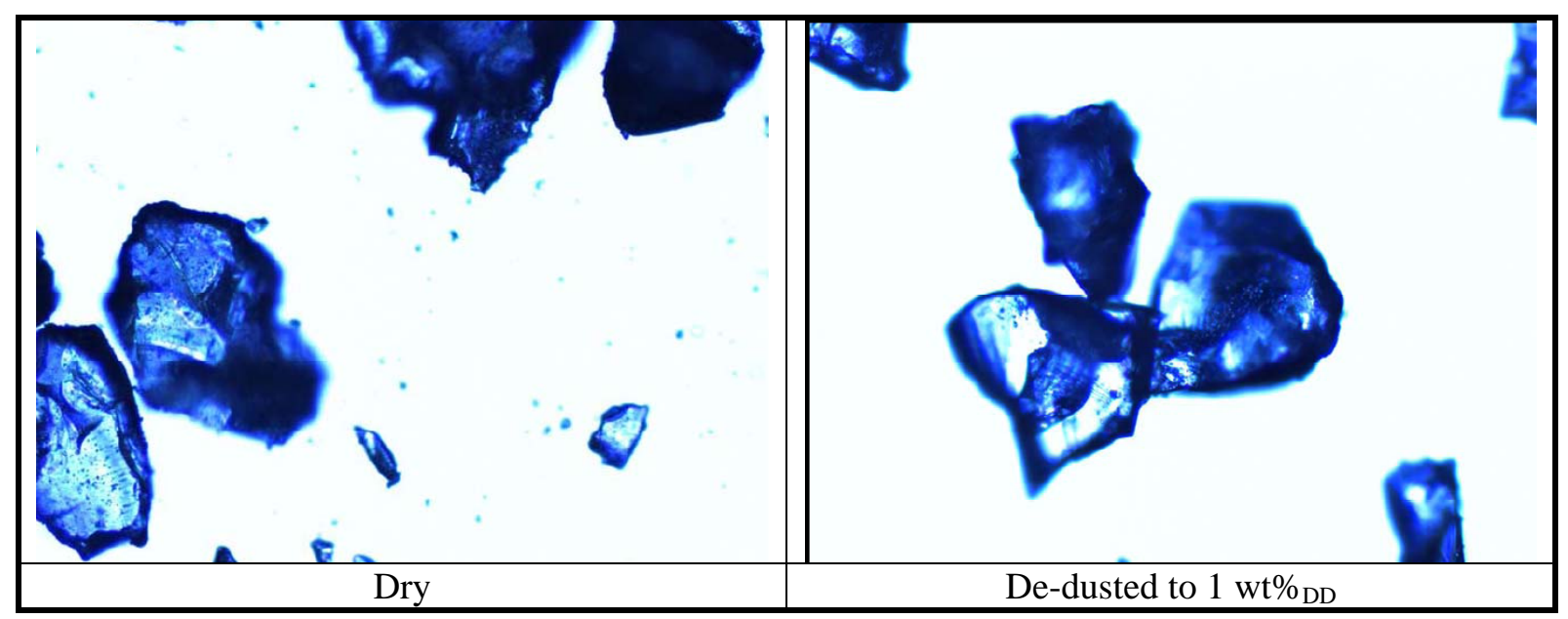

Figure 3-4 Microscopy of Dry and De-Dusted Frit 320

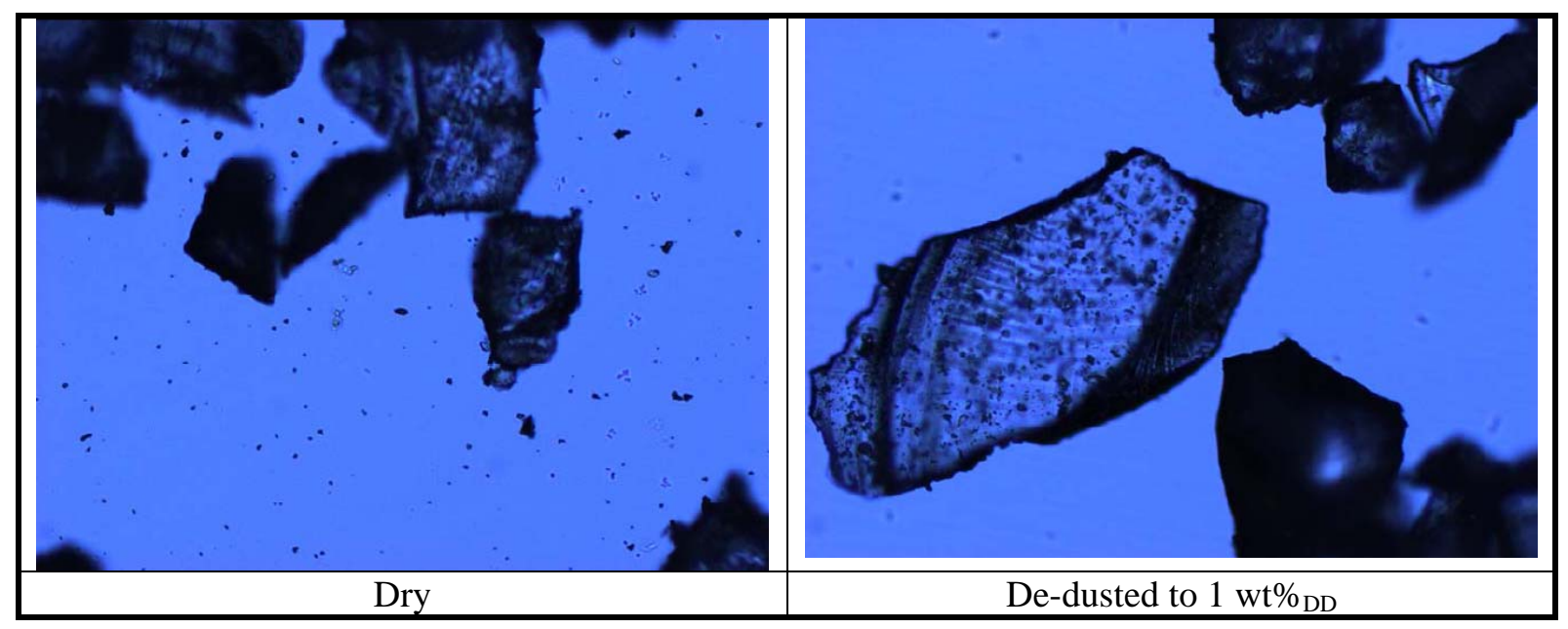

Figure 3-5 Microscopy of Dry and De-Dusted Frit 418

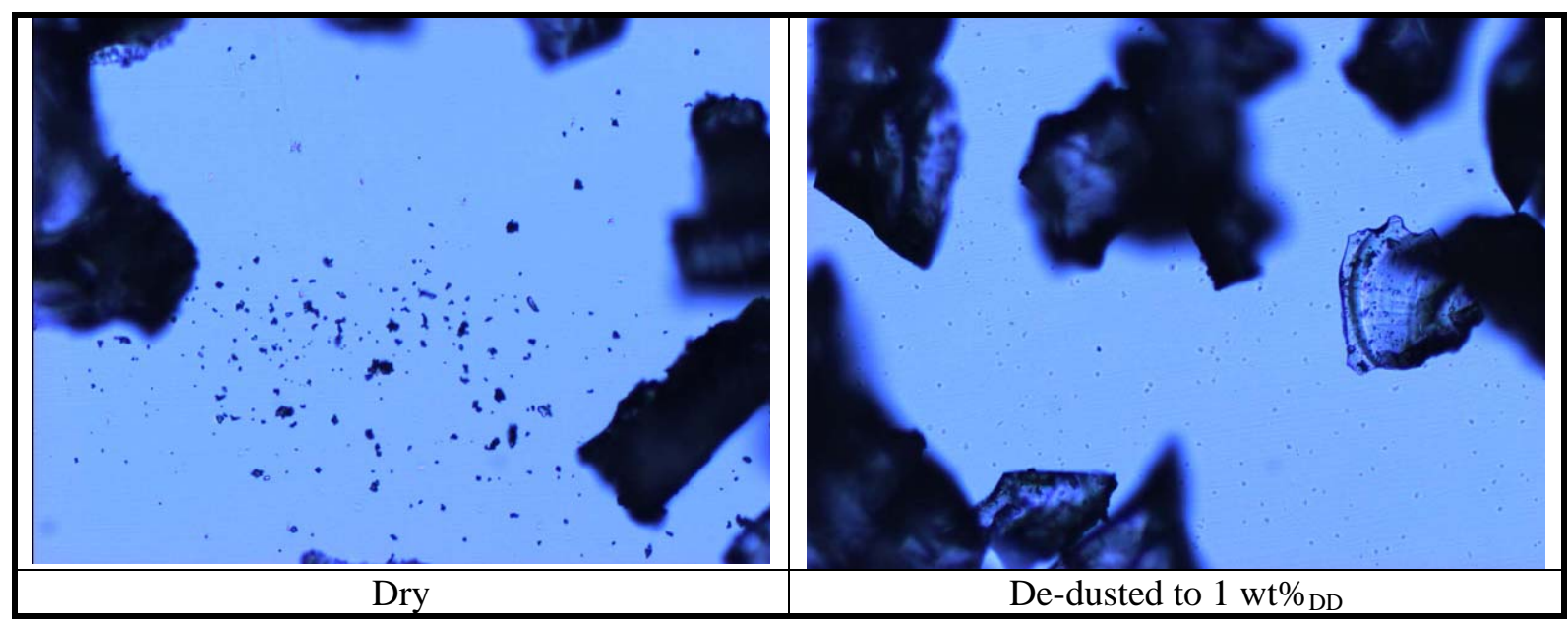

Figure 3-6 Microscopy of Dry and De-Dusted Frit 520 


\subsection{Particle Size Analysis Using Laser Light Refraction}

The Microtrac PSD for the as-received and fines Frit 200 and Frit 418 are provided in Table 3-5 and Table 3-6 respectively. Comparing the results from Table 3-2 to those in Table 3-5 is not possible, due to the different techniques (sieving and light scattering/analysis) used to determine the particle size. The PSD for the as-received frits are provided as information only. The fines are much smaller than the as-received frits, with a mean volume of less than 10 microns and a mean number less than one micron. This PSD data cannot be used to determine mass fraction of fines.

Table 3-5 Microtrac Frit 200 and Frit 418 As-Received

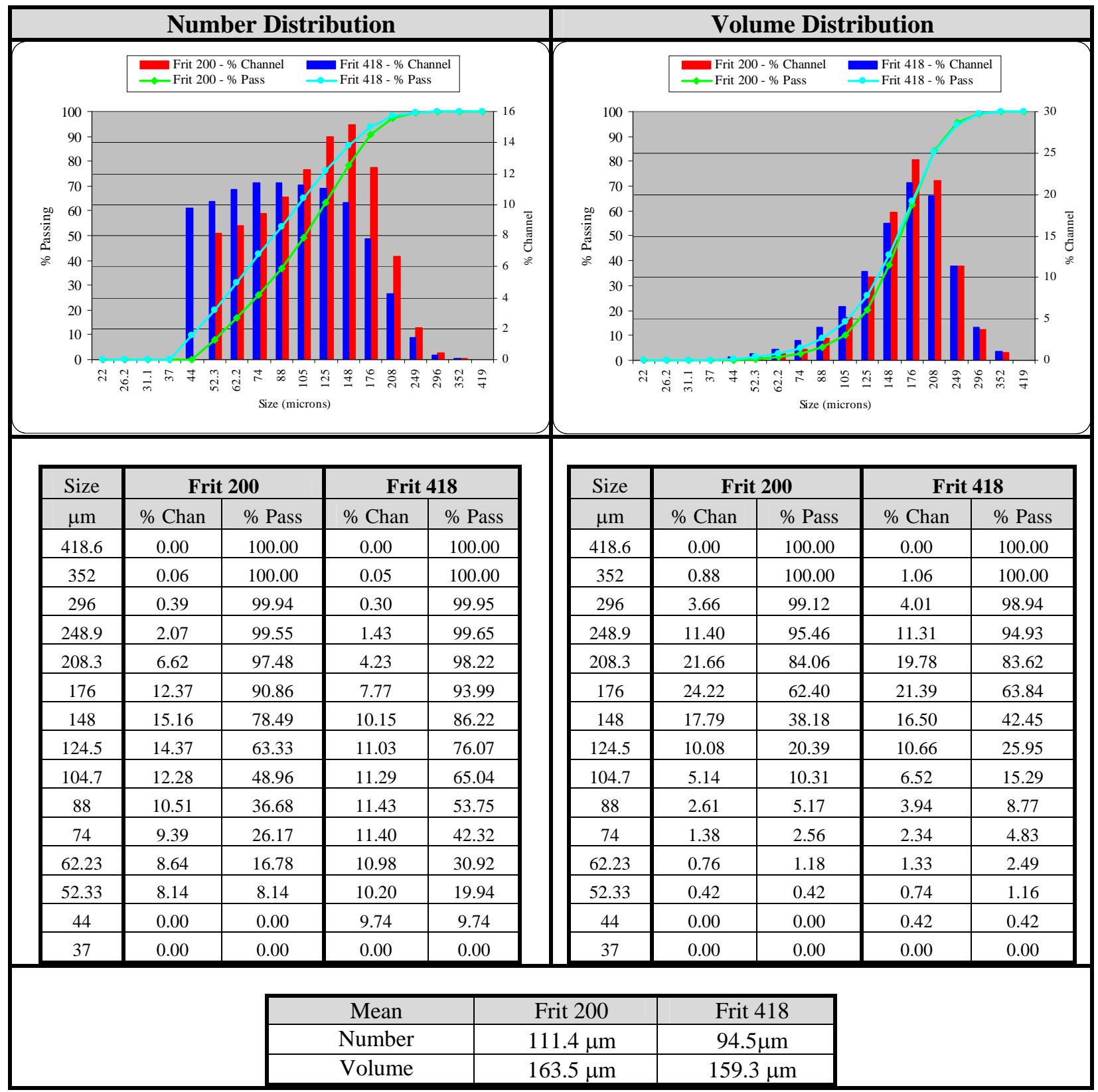


Table 3-6 Microtrac Frit 200 and Frit 418 Fines Particle Size Distribution

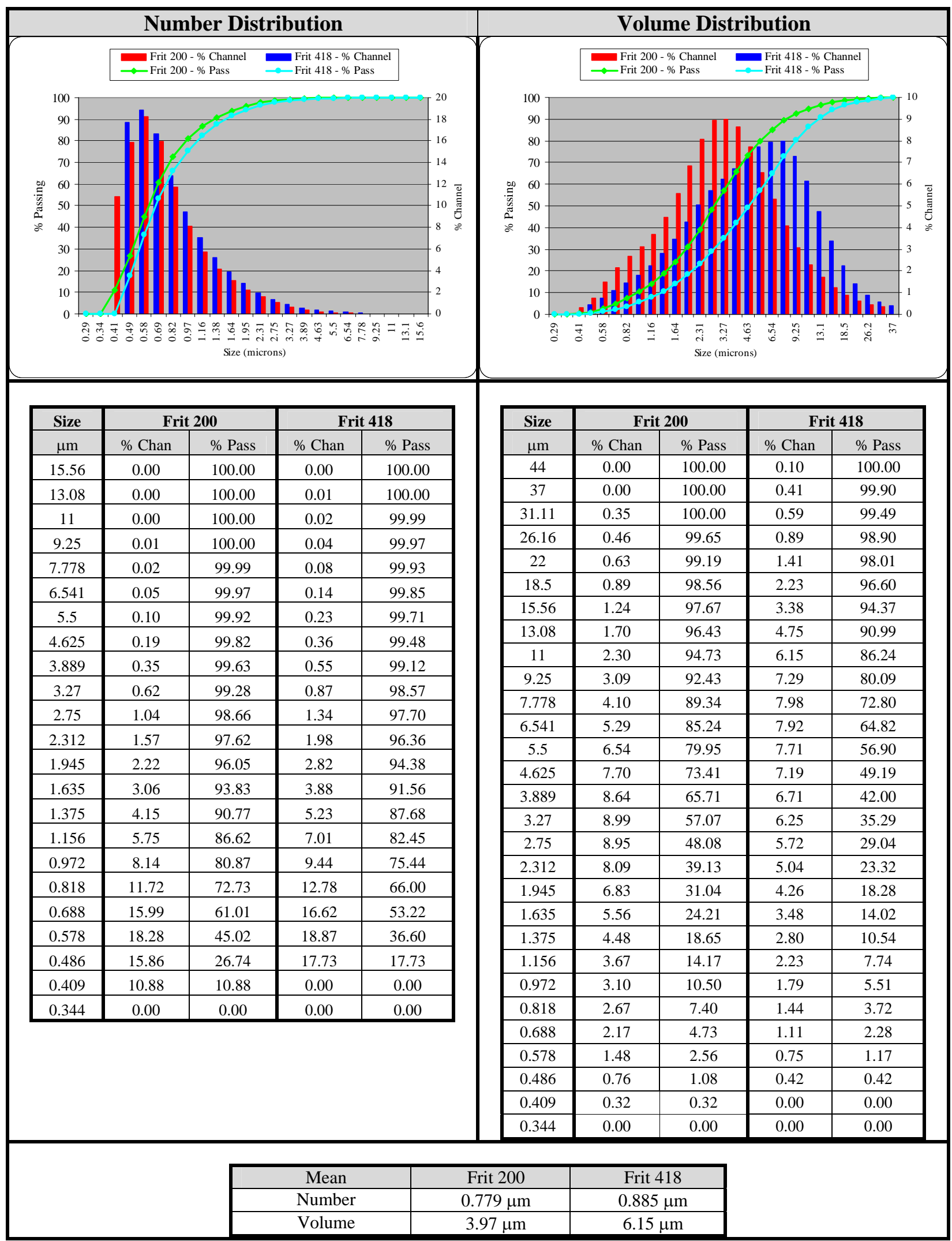


A sample of the fines from Frit 418 was observed using the Olympus microscope and the results shown in Figure 3-7. The distribution of fines in Figure 3-7 indicated the particles are much less than 20 microns. This is consistent with the fines from the Microtrac PSD data provided in Table 3-6.

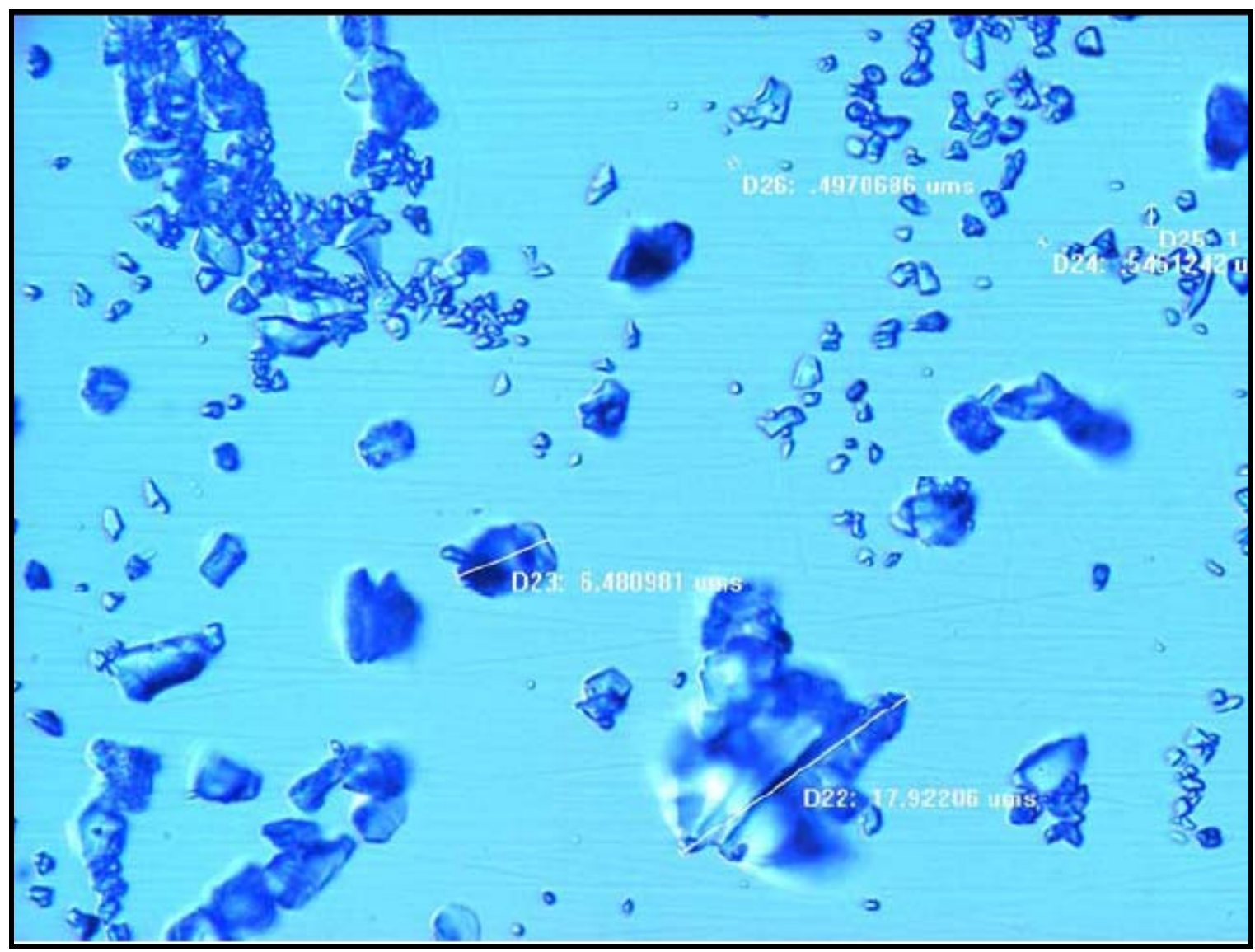

Figure 3-7 Fines in Frit 418 Observed using Microscope

\subsection{Additional Testing}

The dust generation due to continuous running of the mixer showed that the dust concentration decrease over time, but was still present after 45 minutes as shown in Figure 3-8. The generation of dust shows that mechanical agitation is required to remove the dust particles from the larger frit particles. 


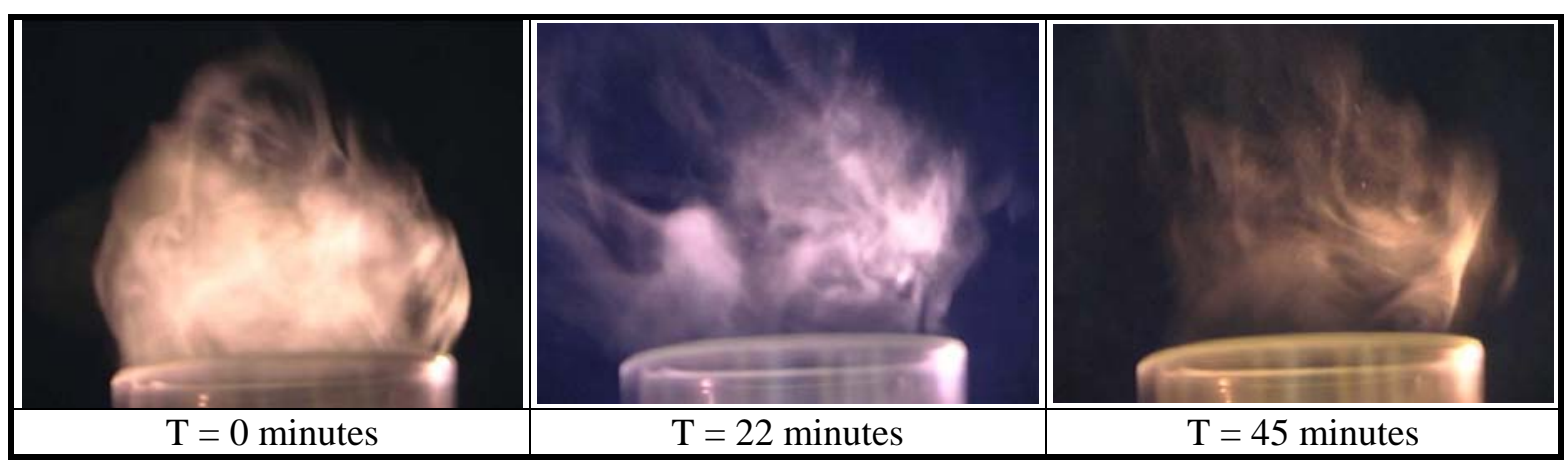

Figure 3-8 Dusting Generation during Continuous Mixing

The combination of mechanical agitation to strip the dust particle from the frit and air to transport the dust particle shows that it is an effective mechanism in accelerating the rate at which the dust particles are transported out of the mixer. This can be seen in Figure 3-9. There was no extended run to determine if a majority of the dust could be removed via this mechanism.

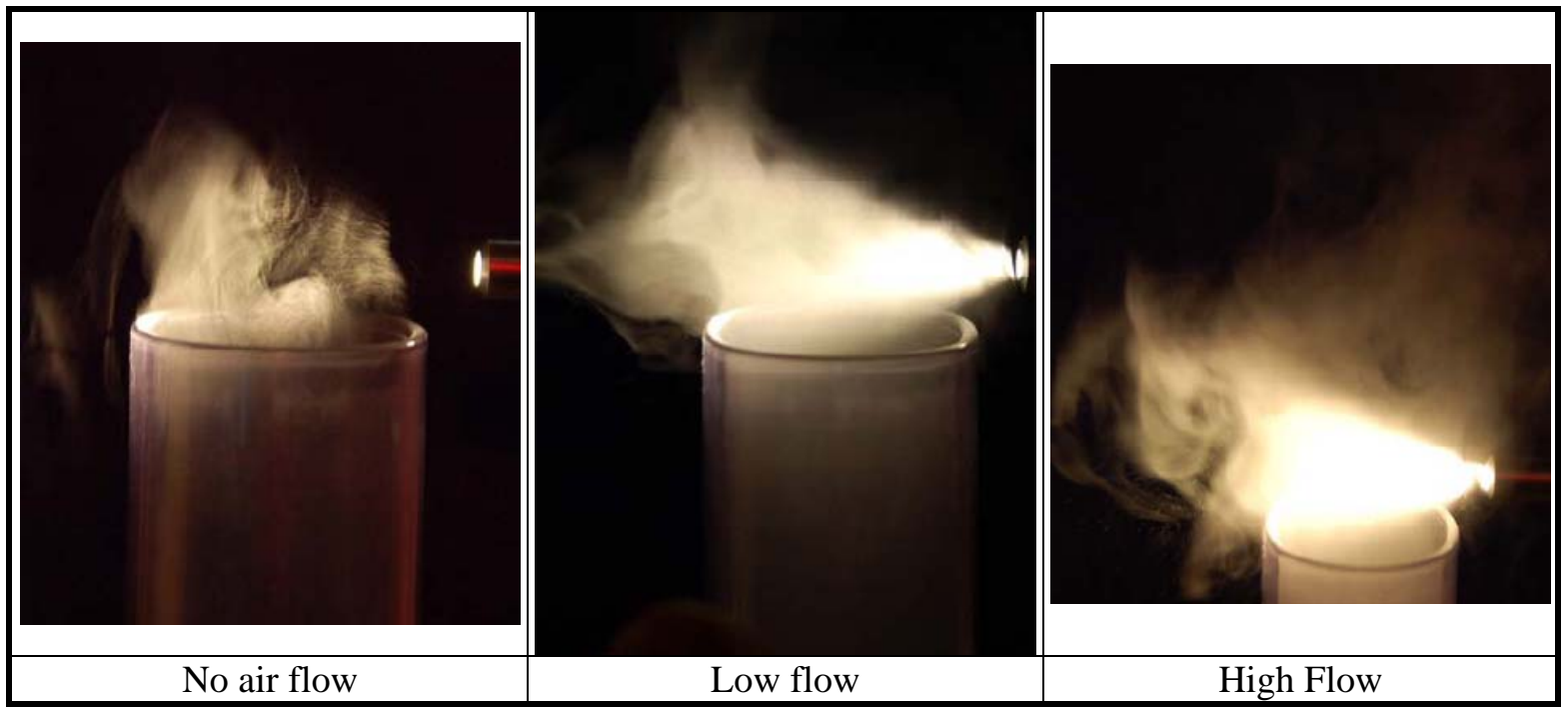

Figure 3-9 Dusting Without and With Airflow

A review of dust removal equipment was performed via an internet search. Various vendors use different techniques to remove the dust or fines. In all the systems, pneumatics is used. Figure 3-10 shows the Gayco Centrifuge separator, which shows the incoming feed accelerated using the fan, which separates the dust from the product and air is then used to remove the dust. The product and fine have two different collection systems and the use of air is minimal in this somewhat closed system. A similar type of fines separator provided by Hosokawa ${ }^{8}$ is also shown in Figure 3-10. There are other types of centrifuge separator provided by Taiheiyo Engineering, called a Classiel classifer shown in Figure 3-11 and by Nisshin Engineering, ${ }^{8}$, called a turbo classifier shown in Figure 3-12.

Another type of separator that used sieves, vibration, and pneumatics is the Fuji Kogyo fines separator, shown in Figure 3-13. 
In all cases, SRNL does not know the efficiencies of fine removal capabilities of these different designs. Testing will be required to obtain this information, if the decision is to de-dust the frit using pneumatics. The benefits of a de-dusted the dry feed using pneumatics should be further investigated, it may be a better method than wetting for de-dusting purposes.

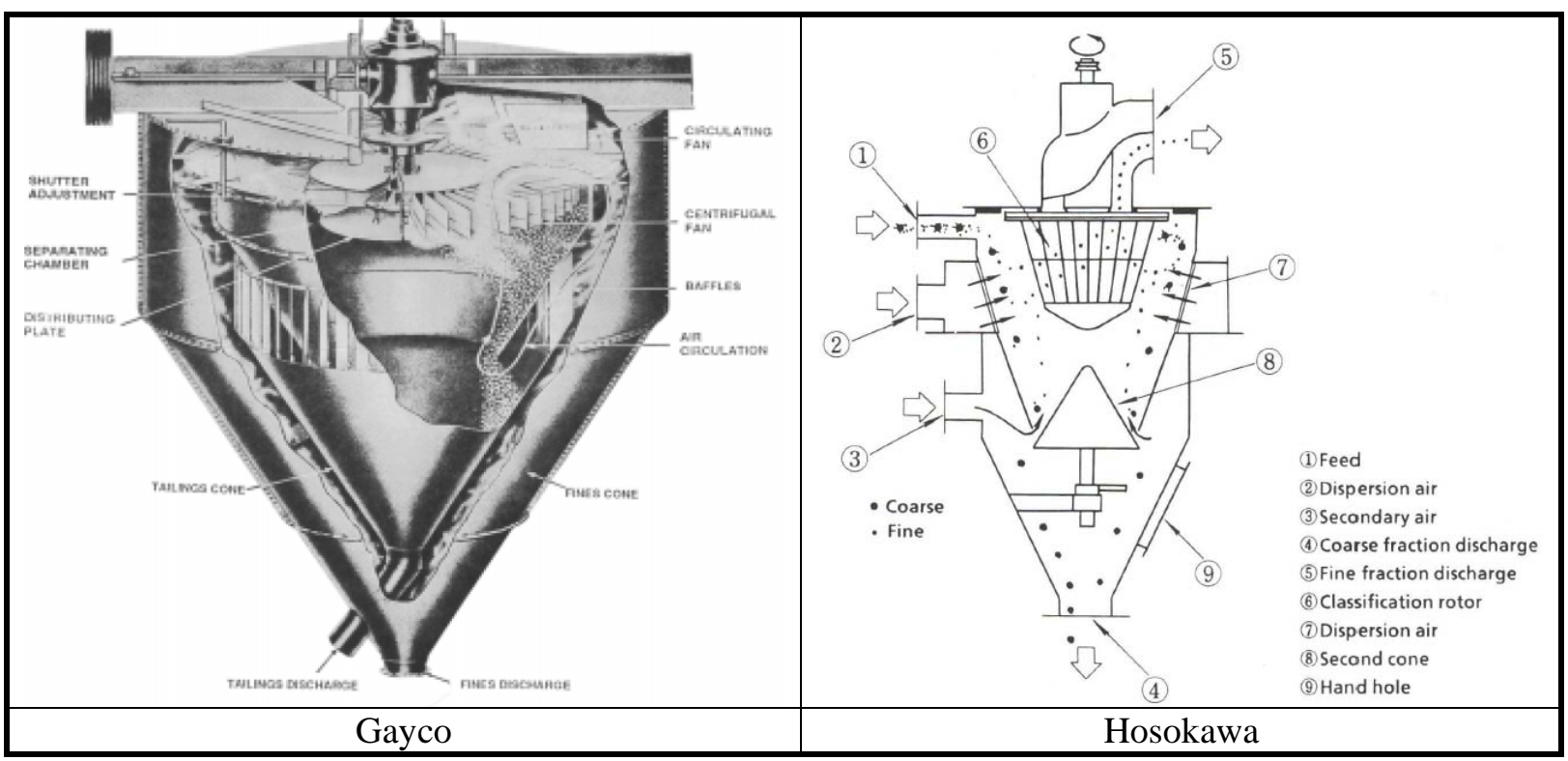

Figure 3-10 Centrifuge Separators

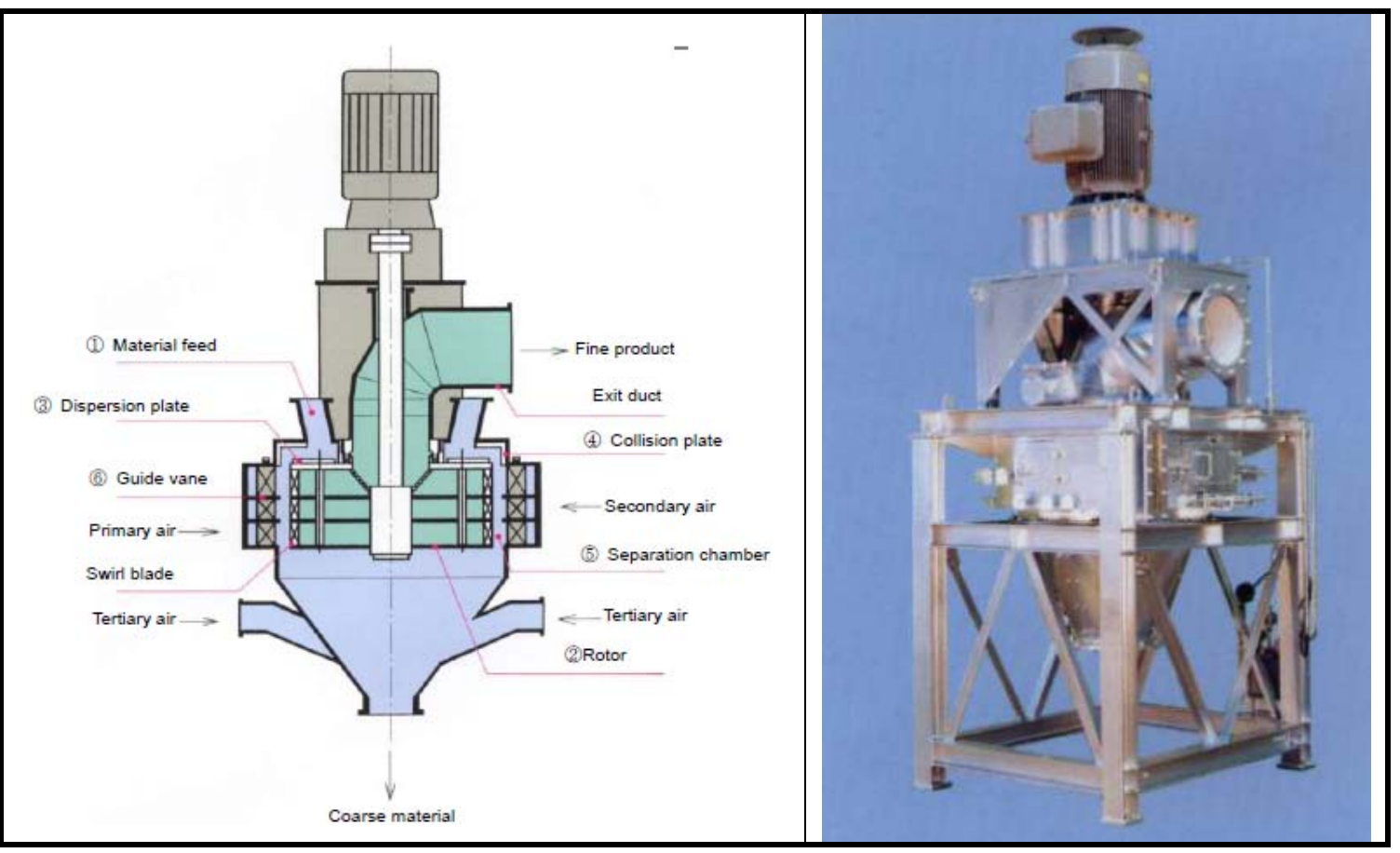

Figure 3-11 Taiheiyo Engineering Classiel Classifier 


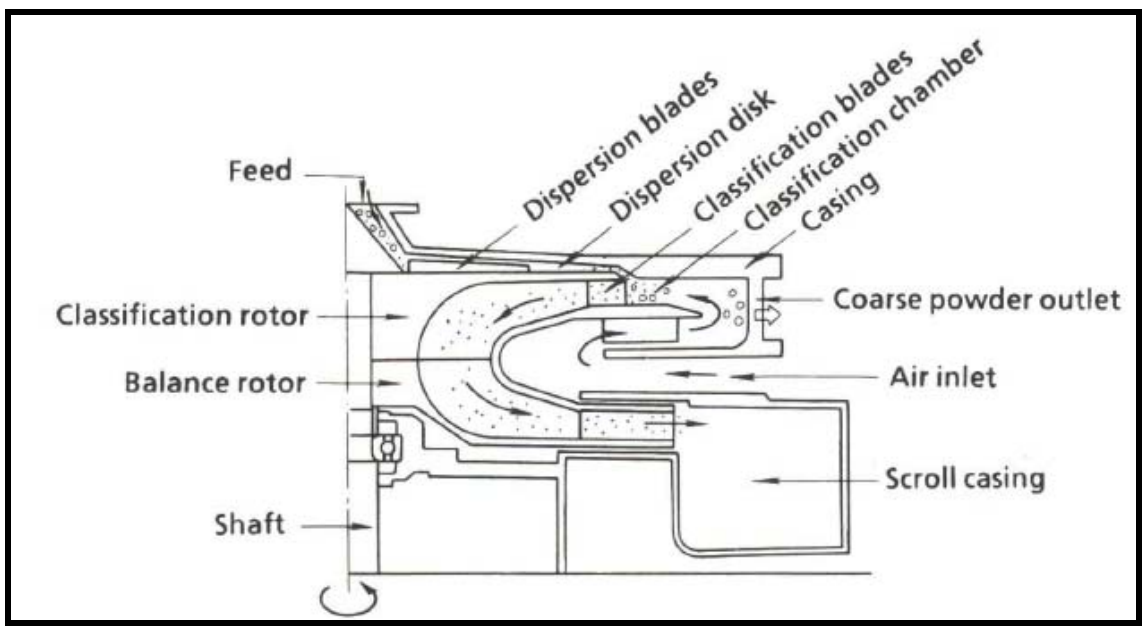

Figure 3-12 Nisshin Engineering Turbo Classifier

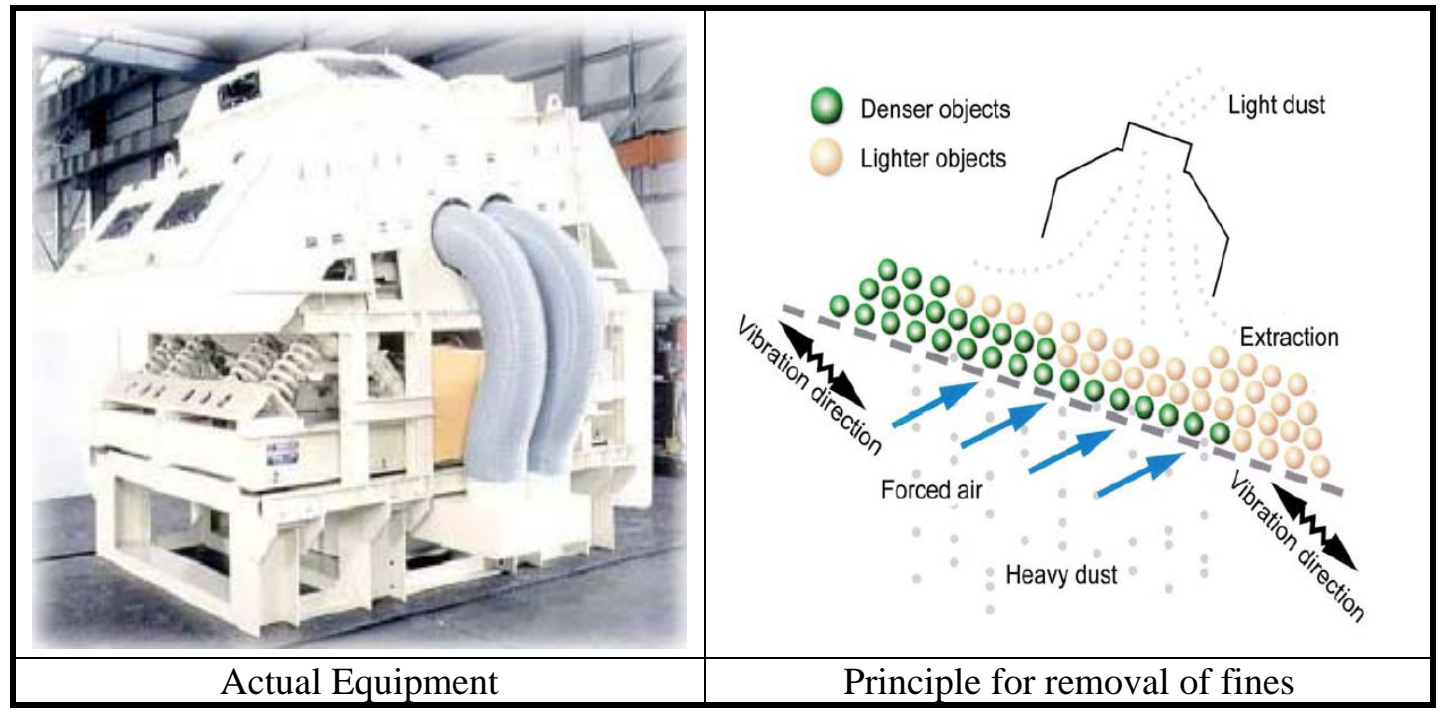

Figure 3-13 Fuji Kogyo Fine Separator

\subsection{Historical PSD Analysis}

Upon analysis of the compiled data, it became evident that the PSD data for the two frit manufacturers were consistently different. Ferro frits, on average, had less small particles (those that pass through a $75 \mu \mathrm{m}$ sieve) than Bekeson frits. The average wt\% that passed through the 75 $\mu \mathrm{m}$ sieve for Bekeson Glass was $5.67 \%$ with a maximum of $8.31 \%$ and minimum of $4.02 \%$, while the average, maximum, and minimum for Ferro Corp. were 3.24\%, 5.28\%, and 2.49\% respectively. The variation of the smaller particles appeared to be fairly even between the frits of the two companies as the Bekeson Standard Deviation for sub-75 $\mu \mathrm{m}$ was $0.91 \%$ and for Ferro Corporation was $0.88 \%$.

The maximum weight percentage to pass through the $75 \mu \mathrm{m}$ sieve from either corporation was $8.31 \%$. The minimum was $2.49 \%$, and the average was $4.95 \%$. 
This variation however, should not necessarily affect the quantity of water necessary for dust mitigation. From the PSD data collected in this study, there is not a distinct correlation between amount of frit passing through the $75 \mu \mathrm{m}$ sieve and $\mathrm{wt} \%_{\mathrm{DD}}$ water required for dust mitigation. Frit 510 had only $1.96 \mathrm{wt} \%$ pass through the $75 \mu \mathrm{m}$ sieve and the average water weight percent was $0.96 \%$ while Frit 304 had $5.06 \%$ pass through the $75 \mu \mathrm{m}$ sieve and an average water weight percent of $0.88 \%$.

Comparing the results of the dry PSD tests carried out in this study with those of the previously studied Frit 418 PSDs shows that all of the frits studied (excluding 165) were within the minimum and maximum values of the previous Frit 418 for wt\% passing through the $75 \mu \mathrm{m}$ sieve. Both of the Frit 418 samples were within $0.5 \mathrm{wt} \%$ of the average for their respective manufacturer (Bekeson and Ferro).

However, if one assumes that the water fraction needed correlates to some degree with the weight percentage of small particles, it is notable that the maximum sub-75 $\mu \mathrm{m}$ fraction for the previously studied frits was $8.31 \mathrm{wt} \%$. The highest fraction in this study was $6.13 \mathrm{wt} \%$. Therefore, there may be frits for which more water than the maximum fraction for this study is necessary for dust mitigation. It is expected that the Frit 165 is a bounding condition, yielding a maximum of $3.11 \mathrm{wt} \%_{\mathrm{DD}}$ for de-dusting.

Table 3-7 Data from Bekeson - Frit 418 Averages

\begin{tabular}{|c|c|c|c|c|c|}
\hline \multirow{2}{*}{ Sieve Size } & \multicolumn{5}{|c|}{ Weight Percent on Sieve } \\
\cline { 2 - 6 } & Average & Minimum & Maximum & STD* & \%STD** \\
\hline $250 \mu \mathrm{m}$ & 0.20 & 0.00 & 0.74 & 0.23 & 115.21 \\
\hline $177 \mu \mathrm{m}$ & 0.76 & 0.28 & 1.31 & 0.27 & 35.84 \\
\hline $105 \mu \mathrm{m}$ & 64.98 & 61.00 & 67.16 & 1.70 & 2.61 \\
\hline $75 \mu \mathrm{m}$ & 28.39 & 26.43 & 30.44 & 1.15 & 4.05 \\
\hline $38 \mu \mathrm{m}$ & 5.67 & 4.02 & 8.31 & 0.91 & 16.04 \\
\hline & $*$ STD $=$ Standard Deviation \\
$* *$ \%ST $=$ STD/Average • $100 \%$ \\
\end{tabular}

Table 3-8 Data from Ferro Corporation - Frit 418 Averages

\begin{tabular}{|c|c|c|c|c|c|}
\hline \multirow{2}{*}{ Sieve Size } & \multicolumn{5}{|c|}{ Weight Percent on Sieve } \\
\cline { 2 - 6 } & Average & Minimum & Maximum & STD* & \%STD** \\
\hline $250 \mu \mathrm{m}$ & 0.07 & 0.00 & 0.16 & 0.06 & 78.94 \\
\hline $177 \mu \mathrm{m}$ & 0.25 & 0.04 & 0.45 & 0.13 & 51.812 \\
\hline $105 \mu \mathrm{m}$ & 66.88 & 63.21 & 70.85 & 2.66 & 3.97 \\
\hline $75 \mu \mathrm{m}$ & 29.56 & 26.17 & 32.52 & 2.16 & 7.32 \\
\hline $38 \mu \mathrm{m}$ & 3.24 & 2.49 & 5.28 & 0.88 & 27.19 \\
\hline & $*$ STD $=$ Standard Deviation \\
& \%STD $=$ STD/Average $\bullet 100 \%$ \\
\end{tabular}




\subsection{Conclusions}

SRNL analyzed six different DWPF frits, 165, 200, 304, 320, 418 and 510 (two different lots of Frit 418 and Frit 200 were tested). All frits but 165 meet DWPF particle size distribution specifications. The quantity of water required to mitigate dusting was determined by visually observing the outlet of a bench scale mixer that was used to mix the water with the frit. The wetted frits, as well as the dry frits were analyzed for particle size distribution, angle required to flow and residual mass of frit remaining on an aluminum oxide plate, and digital microscopy. The results from these tests are;

$>$ Frit 165 was unique to all the others, and had a smaller particle size distribution as compared to all the other frits.

$>$ For all frits, other than Frit 165, the average weight percent (wt $\%_{\mathrm{DD}}$ ) of deionized (DI) water added to the frit to de-dust was $0.95 \mathrm{wt} \%_{\mathrm{DD}}$ with a standard deviation of 0.11 wt $\%_{\text {DD }}$. The maximum weight percent of DI water for a given test was $1.17 \mathrm{wt} \%_{\mathrm{DD}}$.

$>$ For Frit 165, the average and maximum weight percent of DI water to de-dust was 3.05 and 3.11 weight percent respectively. This is expected, since this frit contained a larger fraction of smaller particles compared to the other frits.

$>$ Angled plate tests of wetted and dry frit on the aluminum oxide plate showed that the wetted frit required a higher angle to achieve flow and left more material on the plate when the plate was placed at 90 degrees.

$>$ None of the frits tested in this study reached the maximum fines content of the previously tested frits. Because of this, more water may be necessary than the results of these tests indicate.

$>$ Additional angled plate tests suggested that frit wetted to $2.0 \mathrm{wt} \%_{\mathrm{DD}}$ water flows better than frit wetted to $1.0 \mathrm{wt} \%_{\mathrm{DD}}$. However, these tests were not extensive enough to be conclusive.

The effect water had in de-dusting the various frits was observed by both the discharge of the mixer and by microscopy photos. The cohesive properties of water caused the fines (or dust) to stick to the larger frit particles and also caused larger frit particles to adhere to each other.

The frit fines were separated via settling in DI water. The resulting frit is much smaller than that of the as-received frit with a mean volume and mean number particle size of less than 10 microns and one micron respectively.

The use of air to accelerate the removal of fines is an effective mechanism, as was shown when applied to the Braun mixer. To assist in the removal of fines from the larger particles, the larger particles must be mechanically handled to strip the fines from these particles and then the air can transport the fine (or dust). Commercial methods, using air, are available, but their efficiencies in removing the fines are unknown.

A review of the previously analyzed data shows there are differences between the percentage of sub-75 $\mu \mathrm{m}$ particles of frit from Ferro and Bekeson. Comparison of the previous PSD data and the data from this study show that that the frits tested for this study are similar in small particle content to those previously studied. Additionally, it is important to note that none of the frits tested in this study reached the maximum fines content of the previously tested frits. Because of this, more water may be necessary than the results of these tests show. The Frit 165 would be a bounding condition, given its large contribution of small particles, requiring $3.11 \mathrm{wt} \%_{\mathrm{DD}}$ water for de-dusting. 


\subsection{Recommendations}

SRNL recommends the following if a dry feed delivery system is utilized for feed delivery to the SME;

Weight percent water determination for de-dusting for each vendor batch to be processed should be performed prior to processing the frit, if the frit will be pneumatically transported to the SME.

$>$ Use $1.2 \mathrm{wt} \%$ water to frit for scaled testing and/or proof of principle testing, for frit material that has been processed in the same manner as those tested in this report.

$>$ Reduce the quantity of dust/fines present in future frit procurements. Dust reduction could potentially reduce the need for water for de-dusting. Pneumatic systems to remove fines are commercially available and should be evaluated.

$>$ Scaled testing should be performed to evaluate the amount of holdup in transfer lines and to determine whether flushing is required. 
SRNL-STI-2010-00421

Revision 0

\subsection{References}

${ }^{1}$ Schumacher, R. F., E. K. Hansen, T. M. Jones, and J. E. Josephs, ”Interim Report - Evaluation of Wetting Agents to Mitigate Dusting of Glass Forming Chemicals During Delivery to the Melter Feed Preparation Vessel”, WSRC-TR-2003-00209, Rev. 0, June 2003.

2 "Handbook for Dust Control in Mining", Department of Health and Human Services, IC 9465, 2003.

${ }^{3}$ Mody, V., and R. Jakhete, “Dust Control Handbook”, Noyes Data Corporation, 1988.

${ }^{4}$ Hopkins, R. C., "Determine Optimal Water Fraction Required for Dust Mitigation in the SME for the Dry Frit Addition Project”, HLW-DWPF-TTR-20101-0013, Rev. 0, 5-17-2010.

${ }^{6}$ Lambert, M. W., and E. K. Hansen, "Task Technical and Quality Assurance Plan for Testing to Determine Optimal Water Fraction for Dust Mitigation in the SME for the Dry Frit Addition Project”, SRNL-RP-2010-00958, Rev. 0, June 2010.

${ }^{7}$ TTR HLW-DWPF-TTR-2009-0002, "Glass Analyses and Physical Property Measurements for DWPF Frit”

${ }^{8}$ Gotoh, K., H. Masuda, Ko Higashitani, “Powder Technology Handbook $-2{ }^{\text {nd }}$ Edition”, Marcel Dekker, 1997. 
SRNL-STI-2010-00421

Revision 0

\section{Distribution:}

\begin{tabular}{|l|}
\hline A. B. Barnes, 999-W \\
D. A. Crowley, 773-43A \\
S. D. Fink, 773-A \\
B. J. Giddings, 786-5A \\
C. C. Herman, 999-W \\
S. L. Marra, 773-A \\
F. M. Pennebaker, 773-42A \\
C. J. Bannochie, 773-42A \\
J. F. Iaukea, 704-30S \\
R. T. McNew, 704-27S \\
J. E. Occhipinti, 704-S \\
D. K. Peeler, 999-W \\
J. W. Ray, 704-S \\
D. C. Sherburne, 704-S \\
M. E. Stone, 999-W \\
J. M. Bricker, 704-27S \\
T. L. Fellinger, 704-26S \\
R. C. Hopkins, 704-30S \\
E. W. Holtzscheiter, 704-15S \\
J. P. Vaughan, 773-41A \\
M. C. Clark, 704-27S \\
H. M. Pittman, 704-27S
\end{tabular}

